2

3

4

5

6

7

8

9

10

11

12

\title{
Structural and stratigraphic development of Offshore NW Sulawesi, Indonesia
}

Herwin Tiranda ${ }^{1,2^{*}}$, Robert Hall ${ }^{2}$

1. Beicip-Franlab Asia, Suite 18-16, 18 ${ }^{\text {th }}$ Floor, G-Tower, 199 Jalan Tun Razak 50400 Kuala Lumpur, Malaysia

2. Southeast Asia Research Group, Royal Holloway University of London, Egham, Surrey, UK, TW20 0EX

*Corresponding author: Herwin Tiranda (herwin.tiranda@beicip.asia)

This paper is a non-peer reviewed preprint submitted to EarthArxiv. 
The area of the Offshore NW Sulawesi lies between eastern Sundaland (Borneo) and the North Arm of Sulawesi. Possible influences on the basins include Paleogene rifting in the Celebes Sea and Makassar Strait, Neogene subsidence and uplift in Borneo, late Neogene subduction at the present-day North Sulawesi Trench, and displacements related to the Palu-Koro Fault. This study presents the results of structural and stratigraphic framework of the Offshore NW Sulawesi based on interpretation of 2D seismic surveys offshore and multibeam bathymetry. In this study, the Offshore NW Sulawesi region is divided into three parts: the Deepwater Tarakan Basin in the NW, the Muara Sub-basin in the west, and separated from these by the Palu-Koro Fault, the North Sulawesi Fold-Thrust Belt in the east. There is no continuation of the left-lateral strike-slip Palu-Koro Fault to the adjacent area of Borneo via the Muara Sub-basin and Deepwater Tarakan Basin. Both basins developed after extension began in the Middle Eocene associated with oceanic spreading in the Celebes Sea. Since then, sediment was fed to the basins from the east and south, with several episodes of subsidence, particularly during Early Miocene in the Muara Sub-basin. Rapid prograding shelves from eastern Borneo are linked to regional inversion and uplift on land since the Middle Miocene and led to gravity-driven movement in the Deepwater Tarakan Basin which formed toe-thrust faults in the latest Miocene. Deformation in the North Sulawesi FoldThrust Belt is interpreted to have occurred in the latest Miocene or Pliocene to present-day with subduction of Celebes Sea at the North Sulawesi Trench and movement on the Palu-Koro Fault.

\section{INTRODUCTION}

The region of Offshore NW Sulawesi between the North Arm of Sulawesi and Eastern Sundaland (Borneo) has been enigmatic in terms of the nature of the basin and structural development within the area. This area is located in a region where there is a transition between Eastern Sundaland which mainly consists of the continental basement and the Celebes Sea which is mainly oceanic crust (Hall, 2002, 2012; Weissel, 1980). A large part of this area are lies within the complex North Sulawesi fold-thrust belt resulting from southward convergence of the Celebes Sea and underthrusting the North Arm of Sulawesi (Figure 1).

The study area is located within the Offshore NW Sulawesi (Figure 1) and is divided into 3 sub-areas. The North Sulawesi Fold-Thrust Belt is separated from the other 2 sub-areas in the west by the Palu-Koro 
Borneo have been identified as the part of NE Kalimantan Basin (Achmad and Samuel, 1984) or Tarakan Basin (PERTAMINA-BPPKA, 1996). The southern basin, which is also the main basin in the region, is named here as the Muara Sub-basin whereas the deeper part of the outer Tarakan Basin to the north of Muara Sub-basin is named the Deepwater Tarakan Basin. These 2 sub-areas are separated by a prominent structural high called the Maratua Ridge.

The Offshore NW Sulawesi area is almost completely unexplored. However, there are several exploration wells in the Muara Sub-basin (i.e. Karang Besar-1) and Deepwater Tarakan Basin (i.e. Aster-1, Tulip-1, Bougainville-1) with stratigraphic information but limited subsurface study. Moreover, the hydrocarbon exploration in this area during the $19^{\text {th }}$ to $21^{\text {st }}$ century mainly focused on the onshore parts of the Tarakan Basin and shallow water part of the basin. In the north of the study area, which lies within the Tarakan Basin is a well-known oil and gas province, and south of the Mangkalihat Peninsula is the Kutai Basin (Figure 1).

The nature of Offshore NW Sulawesi is still uncertain because the development of the basins is poorly understood, and their structural geometry is not obvious. There are two active subduction zones close to North Sulawesi: the Molucca Plate subducts to the west underneath the eastern part of the North Arm and there is subduction of the Celebes Sea under the central North Arm in a southward direction. All active volcanoes are in eastern North Sulawesi as a result of the Molucca Plate subduction. Recent geological mapping, GPS measurements and palaeomagnetic investigations show that this region has a very complex history including rapid movements and rotations possibly related to Neogene uplift, exhumation, and strike-slip deformation (Silver et al., 1983; Socquet et al., 2006; Surmont et al., 1994; Vigny et al., 2002). The North Sulawesi Trench and Palu-Koro Fault formed around the Late Miocene to Pliocene (Advokaat, 2015; Hall, 1996, 2002, 2012; Watkinson and Hall, 2016).

Further west, next to the Muara Sub-basin, the Maratua Ridge is the structural high parallel to the Maratua Fault Zone (Lentini and Darman, 1996; PERTAMINA-BPPKA, 1996). Several authors (Hidayati et al., 2007; Lentini and Darman, 1996; PERTAMINA-BPPKA, 1996) identified three sinistral wrench faults in the Tarakan Basin. The Semporna Fault in the northern part of Tarakan Basin is considered the northern wrench fault whereas Maratua Fault Zone in the south of the Tarakan Basin is a transpressional 
fault zone interpreted to have formed the Maratua Ridge (Hidayati et al., 2007; Lentini and Darman, 1996; PERTAMINA-BPPKA, 1996). A boundary on the south side of the Muara Sub-basin closer to the coastline of the Mangkalihat Peninsula, has also been interpreted as a major wrench fault continuation of the left lateral Palu-Koro Fault in Sulawesi (Hidayati et al., 2007; Lentini and Darman, 1996; PERTAMINA-BPPKA, 1996). The Muara Sub-basin is considered the transpressional zone formed by these two coupled shear zone (PERTAMINA-BPPKA, 1996). However, there is very limited field evidence of these wrench fault in the onshore area of the Tarakan Basin (PERTAMINA-BPPKA, 1996).

A number of plate reconstruction models have been proposed. Early Cenozoic rifting is marked by the separation of western Sulawesi from Borneo (Daly et al., 19991; Hall, 1996, 2002, 2012; Letouzey et al., 1990; Pieters et al., 1983) followed by subsidence during the Oligo-Miocene in Borneo (Hall, 2002, 2012). Significant uplift in Borneo has occurred from the Middle Miocene until the present day (Hall, 2002, 2012). North Sulawesi Trench and Palu-Koro Fault formed later during the Late Miocene to Pliocene (Hall, 2002, 2012; Watkinson and Hall, 2016). Therefore, understanding the structural and stratigraphic development of Offshore NW Sulawesi is very important in evaluating prospectivity of the basins. This paper focuses on revealing the structural and stratigraphic development of Offshore NW Sulawesi based on 2D seismic reflection data and multibeam bathymetry map to get a better understanding of the basin history related to the regional tectonic history of the area so that potential petroleum systems can be identified and assessed.

\section{DATASET AND METHODOLOGY}

During 2005 to 2009, PGS acquired and processed 2D seismic datasets as a part of their EJMM MegaProject over offshore basins from East Java, Makassar, and Muara regions which provided significantly increased coverage and improved resolution. The area of interest is covered by a 2D seismic survey (Figure 2), which consists of 45 2D seismic lines (25 cross-lines trending NE-SW and 20 in-lines trending NW-SE). It was processed by PGS using Kirchhoff pre-stack time migration (PSTM) and covers an area of approximately 49,000 km², with line spacing ranging from $12 \mathrm{~km}$ to $114 \mathrm{~km}$. This also provides the dataset with a total length of approximately 3,940 km and extends to a depth of 9 seconds two way time (TWT). 
High-resolution multibeam bathymetry was provided by GeoData Ventures (GDV) covering an area of approximately 65,000 $\mathrm{km}^{2}$ of Offshore NW Sulawesi (Figure 2) and it was also incorporated in the study to see morphological features, sedimentary features, and active tectonic structures of Offshore NW Sulawesi. The multibeam bathymetry or Multibeam Echo-sounder Systems (MBES) record the images of seabed topography by measuring the time for a pulse to travel to the seabed and reflect to a receiver at the sea surface (Gafeira, 2010). Information about multibeam mapping and data processing which can measure sea floor depth to within a few centimeters using a high resolution echo sounder can be found in Orange et al. (2010). It has 25-15 m resolution and has been processed to a shaded-relief map by mimicking the effect generated by illumination at a low angle using Geographic Information System (GIS) software ArcMap 10.3.1 and ER Mapper. The shaded-relief map provides exceptional details of seafloor morphology, sedimentary features, and active geological structures as interpreted in Figure 3.

The methodology used in this paper is based on the recognition of seismic stratigraphy units and their stratal termination concepts (i.e. onlap, toplap, downlap, offlap, and truncations) according to Mitchum Jr et al. (1977). Time structure maps were built to understand the basin geometry, structural evolution, and Tarakan Basin and Muara Sub-basin leading to a stratigraphic framework of Offshore NW Sulawesi.

\section{SEISMIC STRATIGRAPHY AND STRUCTURAL CHARACTERISTIC} three different sub-areas which are the Muara Sub-basin, Deepwater Tarakan Basin, and North Sulawesi sedimentary process at basin scale. Isochron maps which show relative sediment thickness are also provided to explain the basin geometry and evolution. The new work was integrated with pre-existing studies such stratigraphic records from published old wells within the study area (Atzeni and Guritno, 2003; BP, 2000; PERTAMINA-BPPKA, 1996; Sunaryo et al., 1988; Wilson et al., 2007). Those data brought additional sedimentary and stratigraphic interpretations for Cenozoic units particularly in the Deepwater Fold-Thrust Belt. Characteristics of seismic stratigraphy and structural development within these three subareas are described in this chapter. Each area developed with a different history of both structure and stratigraphy. Moreover, prominent structural highs and faults-bounding these three subareas make it complex to correlate between them as discussed below and summarized in Figure 4. Most of the interpretation has focused on the Muara Sub-basin and Deepwater Tarakan Basin where there is good 
seismic coverage. The North Sulawesi Fold-Thrust Belt has significant differences from the Muara Subbasin and Deepwater Tarakan Basin in structure and stratigraphy indicating a different tectonic history. An overview of composite seismic stratigraphy units across the three different sub-areas is summarized in Figure 4.

\subsection{Seismic stratigraphy of the Muara Sub-basin}

The Muara Sub-basin seismic stratigraphy has been divided into several seismic units based on seismic reflection characteristics, and major changes in seismic facies or unconformities marked by stratal terminations. Several wells with stratigraphic age control from published papers were used in this study and tied to the seismic packages particularly Karang Besar-1 well in the Muara Sub-basin (Sunaryo et al., 1988) and Makassar-A1 which is south of the Mangkalihat Peninsula (Camp et al., 2009) as shown in Figure 5. Based on stratigraphic information from the wells, the stratigraphy units in the Muara Sub-basin range in age from Eocene to Quaternary. There are eight main seismic units observed in the Muara Subbasin which are, Unit X (Middle Eocene equivalent), Unit A (Upper Eocene equivalent), Unit B (Lower Oligocene equivalent), Unit C (Upper Oligocene equivalent), Unit D (Lower Miocene equivalent), Unit E (Middle Miocene equivalent), Unit F (Upper Miocene equivalent), and Unit G (Pliocene-Recent equivalent). The summary of seismic characteristics for each unit is shown on seismic line in Figure 6.

\subsubsection{Unit X}

Unit $\mathrm{X}$ is characterized by variable amplitudes with discontinuous, chaotic reflections, and a low frequency seismic package (Figure 6). The internal seismic character of this unit is disrupted which makes it difficult to identify stratal terminations within it. In some of the seismic profiles, the top of this unit is marked by high amplitudes interpreted as a basal unconformity within this area. Several high amplitude reflections were observed as a localized feature within this unit which might indicate an acoustic basement or reflection multiples (Figure 7). This unit is also characterized by a series of faulted blocks with normal faults with planar surfaces cutting through it (Figure 7-Figure 9). However, the depth to which faults can be traced is not obvious.

The top of this unit is interpreted as Top Middle Eocene based on stratigraphic information from Makassar-A1 well in the southern part of Mangkalihat Peninsula according to Camp et al. (2009). The unit 
is equivalent to the Middle Eocene Sembakung Formation and which include deformed volcaniclastics and Danau Formation basement rocks (Achmad and Samuel, 1984; Sunaryo et al., 1988). Possible siliciclastic facies of mixed shale and sandstone are mentioned by Achmad and Samuel (1984) and Wilson et al. (2007).

\subsubsection{Unit A}

Unit A is characterized by variable amplitudes, discontinuous and chaotic reflections, and a low frequency seismic package (Figure 6). In several seismic lines, this unit is characterized by continuous reflection with growth strata package terminating at a normal fault which indicates a syn-extensional unit (Figure 9). This unit is deformed into a series of faulted blocks (Figure 7-Figure 9). The top of this unit is interpreted as Top Late Eocene based on stratigraphic control from Makassar-A1 well (Camp et al., 2009). According to Achmad and Samuel (1984) and Sunaryo et al. (1988), Unit A is an Upper Eocene marine siliciclastic facies with localized carbonate build ups.

\subsubsection{Unit B}

Unit B is characterized by high amplitudes, discontinuous and mounded reflections, mound geometry, and a low frequency (Figure 6). On several seismic profiles, this unit is observed as onlapping and downlapping on Unit A (Figure 7-Figure 9). The top of this unit is marked by high amplitude reflections which can be recognized easily within the study area as a regional carbonate unconformity equivalent to the Top Early Oligocene (Achmad and Samuel, 1984; Sunaryo et al., 1988). This unit is less deformed than Unit A and several internal reflection terminate at faults. Build ups and mounded features are the most common seismic reflection pattern (Figure 7-Figure 9). The unit is interpreted as a relatively shallow marine carbonates.

\subsubsection{Unit C}

Unit C has variable amplitudes with continuous and divergent reflections (Figure 6). This unit appears only in the Muara Sub-basin and is characterized by basin fill geometry with low frequency seismic reflections (Figure 7 and Figure 8). Several different stratal terminations are observed within this unit (e.g. toplap, downlap, and erosional truncation) as can be seen in Figure 7 and Figure 8. The top of this unit is interpreted as a local unconformity which is equivalent to the Top Late Oligocene based on 
stratigraphic well control of Karang Besar-1 described by Sunaryo et al. (1988). This unit is equivalent to an Upper Oligocene unit which consists of siliciclastic facies or pelagic and hemipelagic mud. According to Achmad and Samuel (1984) and Sunaryo et al. (1988), the Upper Oligocene unit is dominated by calcareous mudstones of the Mangkabua Formation.

\subsubsection{Unit D}

Unit D is characterized by high amplitudes with continuous and divergent reflection (Figure 6). Most of the reflection patterns are sub-parallel. The basin shows basin fill geometry with high frequency reflections onlapping and downlapping towards Unit C (Figure 7 and Figure 8). The lower part of Unit D is characterized by chaotic and contorted reflections (Figure 8) interpreted as Mass Transport Complex (MTC). The top of this unit is interpreted as a local unconformity that is equivalent to the Top Early Miocene based on the Karang Besar-1 well described by Sunaryo et al. (1988). The depositional environment and lithology based on seismic stratigraphy is a shallow to a deep marine environment dominated by pelagic and hemipelagic mud. This unit is equivalent to the Lower Miocene Birang Formation of Achmad and Samuel (1984) and Sunaryo et al. (1988).

\subsubsection{Unit E}

Unit E has variable amplitudes with continuous and sigmoid reflections (Figure 6). The internal seismic pattern shows a progradation geometry downlapping towards Unit D. The high seismic frequency package is possibly dominated by siliciclastic facies of delta to pro delta facies. The top of this unit is interpreted as a local unconformity in the Muara Sub-basin that is equivalent to the Top Middle Miocene based on stratigraphic control from the Karang Besar-1 well described by Sunaryo et al. (1988). In several sections, particularly eastern edge of the Mangkalihat Peninsula, erosional truncation marks the boundary of Unit E and Unit F above shown in the interpreted seismic section of the SW part of MA08-04 (Figure 9).

\subsubsection{Unit F}

Unit F has high amplitudes, continuous, and sigmoid reflections. The internal seismic pattern shows progradation geometry with a high frequency seismic package that downlaps towards Unit E (Figure 7- 
control from Karang Besar-1 described by Sunaryo et al. (1988). This unit is equivalent to the Upper Miocene Menumbar Formation described by Achmad and Samuel (1984) and is a marine siliciclastic facies from a prograding delta shelf.

\subsubsection{Unit G}

Unit $\mathrm{G}$ is characterized by high amplitudes and continuous, and sigmoidal reflections (Figure 6). Internal reflections show as progradation geometry with high frequency downlapping towards Unit F (Figure 7Figure 9). The top of this unit is the seabed. This unit is equivalent to the Pliocene-Recent according to stratigraphic well control in the Karang Besar-1 well illustrated by Sunaryo et al. (1988). It is mixed siliciclastic and carbonate facies from a prograding delta.

\subsection{Seismic stratigraphy of the Deepwater Tarakan Basin}

The Deepwater Tarakan Basin seismic sequence has been divided into several seismic packages. Stratigraphic control from one well (Bougainville-1) taken from published paper (Putra et al., 2018) and unpublished post-drill report (BP, 2000) was used to build the seismic stratigraphic framework in the basin (Figure 11). However, the Bougainville-1 well only reach the Upper Miocene stratigraphic unit as the total depth of the well. Thus, the age of seismic stratigraphy units older than Late Miocene was predicted in this paper (see section 4). Six seismic units have been identified within the Deepwater Tarakan Basin area which are, Unit X1, Unit C1, Unit D1, Unit E1, Unit F1, and Unit G1 (Figure 12).

\subsubsection{Unit X1}

Unit X1 has variable amplitudes, discontinuous and chaotic reflections, and low frequency (Figure 13Figure 15). The top of this unit shows mounded geometry possibly related to an underlying volcanic edifice at an average depth of 9 secs TWT which can be easily traced within this area as a basal unconformity. The internal seismic pattern has localized high amplitudes with parallel reflections. This might be basaltic sills. The lithology of this unit is interpreted as oceanic crust with several local parallel basaltic sills. 
Unit C1 is characterized by variable amplitudes with continuous and subparallel reflections. The reflection pattern of this unit becomes chaotic and contorted in the deformed zone of the Deepwater Tarakan Toe-Thrust (Figure 13-Figure 15). The low frequency seismic package downlaps towards Unit X1. The unit is interpreted as marine siliciclastic facies of pelagic mud and sandstone.

\subsubsection{Unit D1}

Unit D1 has variable amplitudes with parallel and subparallel reflections. The reflection pattern is partly continuous but becomes contorted in the Deepwater Tarakan Toe-Thrust (Figure 13-Figure 15). The seismic frequency is relatively low and reflection downlaps towards Unit C1. This unit is interpreted as marine turbidites with mixed siliciclastic facies.

\subsubsection{Unit E1}

Unit E1 is characterized by variable amplitudes with parallel reflections. The reflections are partly continuous and become contorted in the deformed zone of the Deepwater Tarakan Toe-Thrust (Figure 13-Figure 15). The seismic frequency is relatively high. Stratal terminations at the base of the unit as it downlap on Unit D1. This unit is probably marine siliciclastic facies dominated by hemipelagic and pelagic mud.

\subsubsection{Unit F1}

Unit F1 is characterized by high amplitudes, parallel and continuous reflections, and high frequency (Figure 13-Figure 15). Although the reflections are slightly deformed and chaotic in the deformed zone of the Deepwater Tarakan Toe-Thrust, most of this unit has parallel and continuous reflections. This unit downlaps on Unit E1. The top of this unit is equivalent to the Late Miocene according to the stratigraphic well control from Bougainville-1 described by BP (2000). This unit is equivalent to the Upper Miocene Tabul and Santul Formations described by Achmad and Samuel (1984) which could be equivalent to the Upper Menumbar Formation and is a marine siliciclastic prodelta facies from a prograding delta shelf. 
Unit G1 is characterized by high amplitudes, parallel continuous reflections, and high frequency (Figure 13-Figure 15). Internal features within this unit include, for example, local incisions infilled with sediment. This unit also shows growth strata packages on top of the Deepwater Tarakan Toe-Thrust with onlap onto Unit F1. The bottom part of Unit G1 downlaps on Unit F1, especially in the basinward section. According to the stratigraphic well control from Bougainville-1 (BP, 2000), the top unit is equivalent to the Top Pliocene-Recent which also pointed to the Tarakan and Bunyu Formations described by Achmad and Samuel (1984). The unit is marine shale facies with thin limestone beds of a prodelta environment (Achmad and Samuel, 1984).

\subsection{Seismic stratigraphy of the North Sulawesi Fold-Thrust Belt}

The North Sulawesi Fold-Thrust Belt seismic sequence has been divided into two main seismic units which are named the Lower Unit and Upper Unit. There is no stratigraphic well control within this area. The seismic stratigraphy is based on seismic reflection characteristics.

\subsubsection{Lower Unit}

The Lower Unit is characterized by variable amplitudes with parallel and chaotic reflections, and low frequency (Figure 17-Figure 18). The most obvious feature of this unit is a highly deformed character that is related to a fold-thrust belt. Several erosional truncations are observed within this unit. Possible lithologies for this unit include mixed basement and cover rocks with volcaniclastic-siliciclastic facies.

\subsubsection{Upper Unit}

The Upper Unit is characterized by variable amplitudes with parallel reflections and high frequency seismic reflections (Figure 17-Figure 18). Growth strata are obvious from reflection patterns in this unit. The lower part shows stratal termination on the Lower Unit (e.g. downlap and onlap). The unit is interpreted as a marine pelagic and hemipelagic mud dominated facies. 


\subsubsection{Muara Sub-basin}

Several different tectonic phases can be recognized from structures of the Muara Sub-basin. In the Muara Sub-basin, the oldest structures are below the basal unconformity in Unit X and are interpreted as the result of pre-Eocene folding and thrusting. Then there was a phase of uplift and erosion to produce the basal unconformity. The extensional phase which initiated rifting is identified from faults seen on seismic lines (Figure 7-Figure 9), followed by deposition of Unit A (Upper Eocene). The phase of extension was inactive later and is interpreted as the end of rifting followed by the break-up unconformity in the Muara Sub-basin. Unit B was then deposited unconformably on top of Unit A (Figure 7-Figure 9).

However, there was some reactivation of normal faulting seen on seismic lines which cut through Unit B (Figure 7-Figure 9) and normal faulting seems to continue into the younger unit. But during the deposition of Unit C, Unit D, Unit E, Unit F, and Unit G almost no significant normal faulting is observed on seismic lines as shown on the time structure map (Figure 10). Unit C infilled locally in the Muara Subbasin during the Late Oligocene (Figure 10). Thick sediment of Unit D is interpreted as the result of rapid subsidence and sedimentation during the Early Miocene (Figure 7 and Figure 8).

Inversion and uplift caused Unit E to prograde to the NE during the Middle Miocene. Inversion of normal faults is interpreted to have caused major uplift in the Mangkalihat High and adjacent area which contributed sediment to the Muara Sub-basin. The inverted normal faults are basement-involved structures and affected all units as observed on seismic (Figure 9). During the period of inversion, Unit F (Upper Miocene) and Unit G (Pliocene-Recent) were deposited in the Muara Sub-basin. Inversion seems to continue to the present day as seismic reflections of Unit $\mathrm{G}$ show erosional truncation at the seabed (Figure 9).

\subsubsection{Deepwater Tarakan Basin}

The Deepwater Tarakan Basin is dominated by a fold-thrust belt which is characterized by an imbricated fault-propagation fold system (Figure 13-Figure 15). In the contractional deformation province, the sequence of thrusting tends to younger basinward. This is interpreted as a gravity-driven structure as observed in several seismic lines (Figure 15). Unit X1 is a relatively undeformed unit with morphology 
features that are interpreted as a volcanic edifice forming part of the Eocene oceanic basement (Figure 13 and Figure 14). Unit C1, Unit D1, Unit E1, and Unit F1 observed on seismic are interpreted as the depositional stage during the Late Eocene to Late Miocene in the Deepwater Tarakan Basin.

The timing of the development of toe-thrust faulting in the Deepwater Tarakan Basin is interpreted to have occurred in the Latest Miocene or Pliocene, post-deposition of Unit F1. Seismic lines show the unit above F1 is lying unconformably on top of Unit F1 as syn-kinematic and post kinematic units (Figure 13Figure 15). The regional detachment level of this toe-thrust fault is interpreted to be in Unit C1 (Upper Eocene to Oligocene) and is suggested to have been triggered by a gravity-driven mechanism (Figure 15 and Figure 16). Little deformation above Unit F1 was developed in the latest stage of fold-thrust belt formation as syn-kinematic units.

Furthermore, observation from multibeam bathymetry shows that the toe-thrust is not visible on the seabed (Figure 3) which implies the uppermost of Unit G1 represents the post-kinematic units. However, based on the seismic interpretation, the growth strata on top of Unit F1 indicates that the faulting may have been active during the earlier stages of deposition of Unit G1 (Figure 13 and Figure 14).

\subsubsection{North Sulawesi Fold-Thrust Belt}

The North Sulawesi Fold-Thrust Belt has a complex structure (Figure 17). The northern edge of this area is bounded by the North Sulawesi Trench which is interpreted as the frontal thrust system of the North Sulawesi Fold-Thrust Belt. It has a different character compared to the fold-thrust belt in the Deepwater Tarakan Basin. Most of the thrust faults dip south and folds have a symmetrical geometry. It is not clear which is the detachment level due to poor seismic imaging in the deeper section with chaotic reflections (Figure 17). However, two trends in the fold-thrust belt are observed within this area which are NE-SW and ENE-WSW (Figure 3).

There is no well control and therefore when deformation began is unknown. Seismic observations show the Lower Unit is deformed (Figure 17 and Figure 18). Subsequently, sediment of Upper Unit is interpreted to have been derived from the south of the North Sulawesi Fold-Thrust Belt, and covered the deformed Lower Unit. Development of the fold-thrust belt seems to continue to the present day as 
observed on seismic since the Upper Unit is also deformed by folds and thrust faults (Figure 17 and

Figure 18). Multibeam bathymetry supports this interpretation. Interpretation suggests the development of extensional basin in the southernmost part of the North Sulawesi Fold-Thrust Belt was the response to development of NE-SW trending thrust faults and ENE-WSW trending thrust faults further north (Figure 3 and Figure 19). Based on observations on land the deformation probably ocurred during the Pliocene to Recent.

\section{DISCUSSION}

\subsection{Age of the basin units}

\subsubsection{Unit X1}

The oldest part of the Celebes Sea is underlain by basaltic basement according to Silver and Rangin (1991) and, based on the studies of the geochemistry from the two holes drilled in the Celebes Sea during ODP Leg 124, has a Mid-Oceanic Ridge Basalt (MORB) affinity. The age of the Celebes Sea crust, based on magnetic anomalies immediately east of the Deepwater Tarakan Basin, is Eocene (Weissel, 1980). This is supported by overlying pelagic sediments which contain radiolarians of Middle Eocene age (Nichols and Hall, 1999; Rangin et al., 1990) and by seismic refraction measurements (Murauchi et al., 1973).

The basal unconformity at the top of Unit X1 in the Deepwater Tarakan Basin shows generally almost flat geometry with a local cone-shaped structure which may indicate carbonate build up or volcanic structure (Figure 13-Figure 15). The latter is much more likely since no aggradation patterns of carbonate builds up were encountered in this unit from the seismic profile. These features are now at an average depth of 7.5 seconds (TWT). Average abyssal water depths in the Celebes Sea are approximately 5 km depth based on the age-depth relationship proposed by Chung-Hwa et al. (1990). Moreover, the interpreted volcanic edifices in the Deepwater Tarakan Basin are up to than $1 \mathrm{~km}$ across which is consisent with typical basaltic volcanoes. We propose the Unit X1 is equivalent to the Middle Eocene basaltic basement in the Celebes Sea.

\subsubsection{Units C1, D1, E1} The contact of Unit C1 and Unit X1 is unconformable over most of the Deepwater Tarakan Basin. Unit C1 has well-stratified reflections which are almost continuous with variable amplitudes and dominate in the 
unit. Similar seismic reflection patterns also observed in the Unit D1, Unit E1, Unit F1, and Unit G1 in the

397 Deepwater Tarakan Basin. The reflections may indicate mixed pelagic hemipelagic mud with minor coarse-grained siliciclastic facies. Some local chaotic reflections are interpreted as Mass-Transport Complexes (MTC) of deep marine turbidites, particularly at the base of Unit C1. The sedimentological record in the easternmost Celebes Sea indicates pelagic to hemipelagic mudstone dominated almost the entire section above the Eocene basaltic basement (Nichols and Hall, 1999).

Middle-Upper Miocene quartz rich turbidite sandstones are discussed by Nichols and Hall (1999). The provenance of the quartz rich sandstones indicates these turbidites were derived from erosion of continental crust (Nichols and Hall, 1999). Plate tectonic reconstructions of the Celebes Sea region which is bordered by Borneo in the west, suggest no relative motion between the Deepwater Tarakan Basin and present-day adjacent areas (Hall, 1996, 2002, 2011, 2012). This implies that sediment influx during the Middle-Late Miocene, as suggested by Nichols and Hall (1999), came from Borneo. Hamilton (1979) also supports the idea that sediments were likely derived from Borneo to the Celebes Sea.

Nichols and Hall (1999) suggested that during the Middle-Late Miocene drainage systems were welldeveloped with large sediment supply of continentally-derived material. This channel system may have allowed the sediments supply to flow downslope from landward of Borneo to the Celebes Sea through the Deepwater Tarakan Basin. Multibeam bathymetry also shows a similar well-developed channel pattern which flows to the Deepwater Tarakan Basin (Figure 3). A further observation from the seismic profile also implies the vertical stacking channel system on the younger units above Unit X1 that broadly has and Samuel, 1984; BP, 2000; PERTAMINA-BPPKA, 1996).

Here, we consider Unit C1 is equivalent to Upper Eocene to Oligocene Sujau Formation and Mangkabua Formation of the Tarakan Basin (Achmad and Samuel, 1984; PERTAMINA-BPPKA, 1996). Unit D1 is equivalent to the Lower Miocene Naintupo Formation whereas Unit E1 is equivalent to the Middle Miocene Tabul Formation (Achmad and Samuel, 1984; PERTAMINA-BPPKA, 1996). 


\subsubsection{Lower Unit and Upper Unit}

As described in the previous chapter, the Lower Unit and Upper Unit of The North Sulawesi Fold-Thrust Belt has different internal seismic reflection pattern. The older unit, Lower Unit, has variable continuity of reflection where mostly are chaotic and deformed while Upper Unit mostly characterized by growth strata package with continuous, high amplitude, and high frequency that lying unconformably the Lower Unit. The development of the North Sulawesi Fold-Thrust Belt may contribute to the different sedimentological record in this region as represented by reflection pattern for each unit.

Possible Pre-Pliocene sediments derived from Borneo to the North Sulawesi Fold-Thrust Belt are quite plausible since the North Sulawesi Fold-Thrust Belt or what Djajadihardja et al. (2004) called as North Sulawesi Accretionary Prism formed during the Latest Miocene or Pliocene which developed by North Sulawesi Trench (Hall, 1996, 2012; Rudyawan, 2016). Lower Unit is much likely equivalent with a PrePliocene unit, similar to those in the Celebes Sea and Deepwater Tarakan Basin.

During the period of the North Sulawesi Trench was developing, Nichols and Hall (1999) suggested that this trench acted as a traps sediment supplied from clastic material transported from Borneo. Possible sediment source to the North Sulawesi Fold-Thrust Belt is from the North Arm of Sulawesi. In this case, Upper Unit is much likely equivalent with Pliocene-Recent unit of the North Arm of Sulawesi.

\subsection{Nature of the basins}

\subsubsection{Muara Sub-basin}

The Muara Sub-basin was developed since the initiation of the extensional event during Middle Eocene which corresponds to the rifting in the Celebes Sea. It has a broadly NNW-SSE trend of normal fault which continue until Late Eocene. During Oligocene, no significant tectonic activity in the Muara Sub-basin and the adjacent area. Thermal subsidence is suggested caused the basin to subside which marked by thick Early Miocene sediment deposited on top the Oligocene unit. Significant inversion since Middle Miocene caused the uplifting in the Mangkalihat Peninsula and prograding shelf to the Muara Sub-basin.

Muara Sub-basin and the Deepwater Tarakan Basin is separated by NW-SE trending Maratua Ridge as a structural high. We see no evidence to support the suggestion of Hidayati et al. (2007); Lentini and 

bounded the Muara Sub-basin and Deepwater Tarakan Basin in the north. A further observation from the seismic and multibeam bathymetry indicates no continuation of Palu-Koro Fault to the eastern part of Borneo (Mangkalihat Peninsula, Muara Sub-basin, and Deepwater Tarakan Basin). However, in the deeper section of the seismic profile immediately north of the Muara Sub-basin, there is a minor pop-up structure developed in relatively very young units (possibly very recent structure) as shown in Error!

Reference source not found.. But, it does not necessarily mean Maratua Ridge is the transpressional wrench fault. Moreover, this structure not affecting the Maratua Ridge it self, contradictive with Hidayati et al. (2007) suggestion.

Maratua Ridge seems to be an older structure which formed in the Eocene as transform fault and related to the formation of Eocene spreading in the Celebes Sea which no longer active since Oligocene (R. Hall, pers. comm. 2017). Interpretation from Fraser et al. (2003) based on the gravity lineament trend of North Makassar Straits indicates NW-SE trending structure in the Mangkalihat Peninsula and Maratua Ridge. However, Fraser et al. (2003) interpreted this lineament as structural freeways that formed transpressional fault of Maratua Faut Zone and Sangkulirang Fault Zone as a continuation of Palu-Koro Fault. Again, no evidence from the seismic and multibeam bathymetry to support the suggestion from Fraser et al. (2003) that Palu-Koro Fault extends towards the Mangkalihat Peninsula and Maratua Ridge.

\subsubsection{Deepwater Tarakan Basin}

The Deepwater Tarakan Basin exhibit well-developed gravity tectonics related structural provinces with extensional and contractional deformation provinces. The contractional deformation provinces are characterized by a toe-thrust fault, whilst the extensional deformation provinces are characterized by detached extensional fault. The transitional zone separating the contractional deformation provinces from extensional deformation provinces. The gravity tectonics in the Deepwater Tarakan Basin is interpreted to have occurred in the Mid-Late Miocene (Hidayati et al., 2007) whereas, recent study from Putra et al. (2018) indicates the deformation of Deepwater Tarakan Basin took place in the late of Early Miocene detaching in the thick shale of Lower Miocene stratigraphy unit which still active until present day. In the transitional zone, shale diapirs or mud pipes can be developed (Morley et al., 2011) as can be seen from Putra et al. (2018) interpretation in the Deepwater Tarakan Basin. 
487 No evidence to support the suggestion of deformation timing and detachment level based on Hidayati et

488 al. (2007) and Putra et al. (2018). Instead, based on our multibeam and seismic observation, the

489 Deepwater Tarakan Basin toe-thrust probably developed in the Latest Miocene or Pliocene postdeposition of Unit F1. It has major NNE-SSW thrust fault which triggered by the gravity driven mechanism caused by major NNE-SSW extensional faulting in the western part of it due to the loading of progradation of large delta system to the east. The uplift onshore since Middle Miocene also possibly controlled to the slope development of the Deepwater Tarakan Basin fold-thrust belt detachment. Moreover, the down-flexing of subducting Celebes Sea slab in the latest Miocene or Pliocene might also allowed gravitational sliding to the Deepwater Tarakan Basin. The thick shale detachment in the Deepwater Tarakan Basin is very unlikely, since seismic observation denotes relatively thin layer possible shale detachment unit above basal unconformity. The deformation of Deepwater Tarakan Basin is most likely inactive since Pleistocene as seen from seismic and multibeam bathymetry that no well-developed fold-thrust belt in the seabed, contrast with Putra et al. (2018) suggestion that the toe-thrust fault development still active in the present.

The rate of sedimentation (V-Sed) model based on Hidayati et al. (2007) shows high sedimentation rate in the contractional deformation provinces in the Latest Miocene and reaches approximately 300-400m/my, coincides with the onset of toe-thrust fault development. In contrast, the rate of sedimentation during Latest Miocene in the extensional deformation provinces reaches approximately $150-200 \mathrm{~m} / \mathrm{my}$ (Hidayati et al., 2007). This has triggered the overpressure generating mechanism caused by disequilibrium compaction due to rapid sedimentation in the contractional deformation province in Miocene (Putra et al., 2018). As a consequences, deformation along a shale detachment will tend to cause dewatering and loss of the initial shale weaknesses, which might not cause reactivation of the initial detachment during the new deltaic cycle or new uplift event onshore (Morley et al., 2011). This might one of the many reasons why the deformation of Deepwater Tarakan Basin toe-thrust fault is inactive since Pleistocene to present-day. 
deformation provinces the sedimentation rate was increased $(+330 \mathrm{~m} / \mathrm{my})$. Growth faulting in the extensional deformation provinces possibly developed huge accomodation space during Late Miocene deformation while large amount of sediments were transported far to the basinward and were accomodated by the development of toe-thrust fault in the contractional deformation provinces. During the next cycle of deltaic sedimentaion, the extensional domain was filled up with large amount Pliocene to Recent sediments with only few amount of sediments was deposited in the basinward (contractional domain). The bulk of Pliocene to Recent sediments probably was trapped in the extensional deformation provinces (Hidayati et al., 2007), implies no triggering mechanims to further reactivate the toe-thrust fault or even to develop new fault.

\subsubsection{North Sulawesi Fold-Thrust Belt}

Development of the North Sulawesi Fold-Thrust Belt is related to the initiation of North Sulawesi Trench which formed in the latest Miocene or Pliocene (Hall, 1996, 2012; Rudyawan, 2016). The development of the North Sulawesi Fold-Thrust Belt was suggested by Djajadihardja et al. (2004) to have formed at $5 \mathrm{Ma}$ as the subduction began.

Observation from the multibeam and bathymetry shows a change of major structural trend in the North Sulawesi Fold-Thrust Belt from broadly NE-SW in the southern part, to ENE-WSW fold-thrust belt trend in the north. This indicates different phases of structural development in the North Sulawesi Fold-Thrust Belt. Djajadihardja et al. (2004) indicate that clockwise rotation of the North Arm of Sulawesi along the Palu-Koro Fault caused the change in trend of the fold-thrust belt from NE-SW to ENE-WSW trend. This idea is also supported by the model postulated by Advokaat (2015).

A further observation from the seismic across North Sulawesi Fold-Thrust Belt also indicates the development of extensional basin and rapid subsidence in the offshore North Arm of Sulawesi. This indication possibly related to the rollback of the southward subducting Celebes Sea since the Pliocene (Advokaat, 2015; Advokaat et al., 2017). Young extension in the North Arm of Sulawesi occurred between 8.5 Ma and 4.4 Ma (Advokaat, 2015) which might relate to the extensional event in a southern offshore of the North Sulawesi Fold-Thrust Belt. 

in the Palu metamorphic rocks (Watkinson, 2011). Furthermore, the northward rollback of the

548 southward subducting Celebes Sea slab which also created the North Sulawesi Trench may have been mechanically linked to the Palu-Koro Fault (Govers and Wortel, 2005; Silver et al., 1983; Vigny et al., 2002) as a subduction-transform edge propagator (STEP) fault (Govers and Wortel, 2005). Walpersdorf et al. (1998) and Bellier et al. (2006) suggested the instantaneous motions by GPS estimated the long term rates based on the interpretation of the slip rate of Palu Koro Fault and the Pliocene rotation. This suggestion is also supported by the observation from multibeam bathymetry and seismic reflection in the North Sulawesi Fold-Thrust Belt that the deformation is still ongoing at the present day.

\subsection{Structural and stratigraphic evolution}

A new structural and stratigraphic evolution model of the Offshore NW Sulawesi is proposed to give an insight into the development of the basins. Schematic summary of interpreted basin evolution model is shown in Figure 20 and Figure 21. The synoptic model is based on observations and interpretation of seismic data and multibeam bathymetry. A literature review was used to provide the regional tectonic context for Offshore NW Sulawesi and adjacent area. Six major stages of structural and stratigraphic evolution from Middle Eocene to present day are recorded in the Offshore NW Sulawesi, as described below.

\subsubsection{Middle Eocene - Late Eocene stage} In eastern Borneo and adjacent areas, extension began in the Middle Eocene (Hall, 2002, 2012) which led to the formation of oceanic crust in the Celebes Sea (Weissel, 1980). The extension phase extended towards the Makassar Strait which initiated the Eocene rifting separating West Sulawesi from Borneo (Hall, 2002, 2012). Extension is also observed in the Muara Sub-basin where rifting initiated in this area at the same time. During this time, the Maratua Ridge acted as a transform fault until the Celebes Sea ceased to spread.

Top Unit X1 represents the basal unconformity above oceanic crust that developed after the cessation of rifting in the Celebes Sea. In the Deepwater Tarakan Basin, minor structuration developed during Middle Eocene time. Most of the rifting features are observed immediately west of it, in the Tarakan Basin 
576 (Lentini and Darman, 1996; Satyana et al., 1999). The basement fabric in the Muara Sub-basin, Top Unit X, 577 shows major NW-SE trending faults which are similar to basement lineaments in the Makassar Straits

578 (Hall et al., 2009; Nur'Aini et al., 2005). Similar features are also observed in the other parts of eastern 579 Borneo in the Kutai Basin (Cloke et al., 1999a; Cloke et al., 1999b) and Tarakan Basin (Lentini and 580 Darman, 1996; Satyana et al., 1999).

581

During the Late Eocene, the channel-like structures trending NW-SE of the Top Unit X1 in the Deepwater Tarakan Basin seems to have accommodated Unit C1 which was transported from the west to the basin.

The depositional environment is interpreted as deep marine with mixed bathyal shales and fine interbedded siliciclastics. Late Eocene radiolarian pelagic and hemipelagic mud which indicates deep marine environment were also found in the Celebes Sea (Nichols and Hall, 1999) which is closer to the Deepwater Tarakan Basin. In the Muara Sub-basin, rifting in the Middle Eocene accommodated Unit A which is interpreted as mixed bathyal shales and fine interbedded siliciclastics transported to the basin from southwest which in the landward direction is dominated by marginal marine coals and siliciclastics (Wilson and Evans, 2002).

\subsubsection{Early Oligocene - Late Oligocene stage}

593 In the Oligocene, there was a deep marine area to the east of Borneo (Hall, 2002). During this period there was no significant tectonic activity in the Muara Sub-basin and Deepwater Tarakan Basin. The Muara Sub-basin and the adjacent area was mostly dominated by widespread carbonate build ups (Achmad and Samuel, 1984; Sunaryo et al., 1988; Wilson and Evans, 2002). Unit B, which is interpreted as carbonate, was unconformably deposited on Unit A. The contact of Unit A and Unit B is interpreted as the breakup unconformity. Deposition continued until the Late Oligocene, and in the Muara Sub-basin Unit C fills the basinal area which was surrounded by carbonate builds up of Early Oligocene age.

The Deepwater Tarakan Basin was a deep marine environment. Little sediment was shed to the east of Borneo during the Oligocene (Hall, 2002). There was no significant change in the sediment source in the Deepwater Tarakan Basin. During this period, Unit C1 is interpreted as transported into the Deepwater Tarakan Basin from the west. Unit C1 is interpreted as a basinal area east of a prograding shelf where bathyal shales and fine interbedded siliciclastics were deposited. 


\subsubsection{Early Miocene stage}

The Early Miocene was marked by a change of sedimentation character in Borneo (Hall, 2002). A large amount of clastic sediments eroded from Central Borneo fed eastern Borneo particularly the Kutai Basin initiating a prograding delta to the east (Hall, 2002). In the Muara Sub-basin, thermal subsidence caused the basin to subside rapidly following the deposition of thick mixed siliciclastic facies of Unit D. Most of the seismic lines show parallel continuous reflections resting on top of Unit C. During this period, there was a significant change of depositional environment from relatively shallow water to a deep-water environment.

Observation of Unit D from seismic indicates contorted and chaotic reflections of a Mass Transport Complex (MTC) passing up into more parallel and continuous reflections of pelagic and hemipelagic mud dominated sediments. Unit D is interpreted as bathyal mixed fine grained siliciclastics. In the Tarakan Basin, the large amount of sediment contributed to the development of a delta system prograding eastward to the Deepwater Tarakan Basin. During this period, the Deepwater Tarakan Basin is interpreted as a deep marine setting with mixed siliciclastic facies of Unit D1 resting on top of Unit C1.

\subsubsection{Middle Miocene stage}

In the Middle Miocene, inversion and uplift caused rapid clastic deltaic deposition in the Tarakan Basin (Satyana et al., 1999). However, several authors suggested the inversion began in the Early Miocene particularly in the Kutai Basin and fed sediment to the Mahakam Delta (Chambers and Daley, 1997). Observations from seismic in the offshore area of eastern and southern part of Mangkalihat Peninsula suggest Middle Miocene inversion and uplift. deposition in the Muara Sub-basin. This is indicated by deposition of Unit E interpreted as a delta prograding to the basinal area in the north. Similarly, in the Deepwater Tarakan Basin, the deltaic system of the Tarakan Basin seems to have prograded to the basinal area. This caused the deposition of Unit E1 which is interpreted as bathyal shales and fine interbedded siliciclastics. 
During the Late Miocene, inversion and uplifting seem to have continued. This is indicated from several seismic sections observed offshore east of Mangkalihat Peninsula which show inverted normal faults. An erosional unconformity and other stratal terminations show evidence of continuation of inversion in the Late Miocene.

As a result, Unit $\mathrm{F}$, which is interpreted as mixed carbonates and siliciclastics, prograded into the Muara Sub-basin and was deposited on top of Unit E. Similarly, in the Tarakan Basin, during the Late Miocene, rapid clastic deposition from landward to the basin caused loading of the prograding delta which is represented by Unit F1. Consequently, normal faulting in the shelf caused gravity driven movements to the Deepwater Tarakan Basin and formed toe-thrust faults in the Latest Miocene. This gravity driven structure is interpreted as detaching on Unit $\mathrm{C} 1$ which is dominated by shales.

Deformation in the North Sulawesi Fold-Thrust Belt associated with the southward subducting Celebes Sea is interpreted to have occurred since the Latest Miocene or Early Pliocene post deposition of Lower Unit during this stage. Deformation of North Sulawesi Fold-Thrust Belt followed by loading of the eastern edge of the Muara Sub-basin and Mangkalihat areas probably caused subsidence of the carbonate features observed offshore east of the Mangkalihat peninsula. Onset of deformation in the North Sulawesi FoldThrust Belt might also has contributed to the loading and clockwise tilting of Celebes Sea, created east dipping detachment ramp that allows gravity driven movements and sediment routing systems to the Deepwater Tarakan Basin.

\subsubsection{Pliocene - present-day stage}

Inversion and uplift in Borneo are interpreted to have continued from the Middle Miocene until the present day as observed from several seismic lines. This caused progradation of the shelf which developed during the Pliocene to Recent in both Muara Sub-basin and Deepwater Tarakan Basin.

In the Muara Sub-basin, Unit G was deposited on top of Unit F as a prograding shelf of mixed carbonate and siliciclastic facies. In contrast, in the Deepwater Tarakan Basin, there were significant decrease of 
caused progradation to the more basinal setting in the east. Development of toe-thrust faulting in the Deepwater Tarakan Basin is most likely inactive since the Pleistocene as observed from seismic where uppermost strata of Unit G1 (Pleistocene-Recent eq. Units) onlap lowermost Unit G1 (Pliocene eq. Units; Figure). Observations from multibeam bathymetry also indicates no well-developed toe-thrust faults at the seabed in the present-day.

Ongoing deformation in North Sulawesi Fold-Thrust Belt which is associated with the subducting Celebes Sea since latest Miocene has a significant impact on the structural and stratigraphic development. The Upper Unit was transported offshore from North Arm of Sulawesi and was unconformably overlie the Lower Unit. During this stage, rollback of North Sulawesi Trench has caused different structural development in the North Sulawesi Fold-Thrust Belt. Since Pliocene, the Palu Koro Fault was mechanically linked to the North Sulawesi Trench. The pattern of fold-thrust belt has rotated clockwise and moved towards the north to its present-day position, whereas immediately north of North Arm of Sulawesi in the offshore extension and subsidence were well developed, followed by deposition of Upper Unit.

\section{HYDROCARBON IMPLICATIONS}

The basin development and evolution have significant implications for the hydrocarbon prospects within the basins. Thus, the structural and stratigraphic evolution model gives an insight into the basin development and petroleum assessment in the basins. Moreover, assessing the basins based on the sediment thickness map using isochron maps can give a better understanding of hydrocarbon potential. This section will focus on the hydrocarbon potential of the Muara Sub-basin and Deepwater Tarakan Basin. The petroleum system elements in the Muara Sub-basin and Deepwater Tarakan Basin are described in this section. Schematic cartoons showing play cross-sections across the depocentre of the Muara Sub-basin and Deepwater Tarakan Basin are summarized in Figure 24 and Figure 25.

\subsection{Source rock}

In the Muara Sub-basin, oil and gas shows have been encountered by several exploration wells through the carbonate build ups (e.g. Taballar-1, Karang Besar-1, and Segitiga-1) as reported by several authors (Achmad and Samuel, 1984; Lentini and Darman, 1996; PERTAMINA-BPPKA, 1996), implying the 
presence of source rocks charging the reservoir. Possible potential source rocks in this basin are the Eocene Maliu Mudstone (PERTAMINA-BPPKA, 1996; Wilson et al., 2007) which consists of predominantly dark-grey shales of an upper bathyal environment (Wilson et al., 2007). Another potential source is the planktonic shales and marls of the deep marine Oligocene Mangkabua Formation and Miocene Birang Formation (PERTAMINA-BPPKA, 1996).

701

Possible source rocks in the Tarakan Basin include coals and siltstones of the Middle Miocene Meliat and Late Miocene Formations (PERTAMINA-BPPKA, 1996; Wight et al., 1992). The Tarakan Basin has more than 14 discoveries of oil and gas fields (PERTAMINA-BPPKA, 1996) generated from source rocks of lacustrine, coastal plain, and deltaic deposits (PERTAMINA-BPPKA, 1996). There are very limited information and exploration in the Deepwater Tarakan Basin. Possible source rocks in the Deepwater Tarakan Basin include deep marine shales of Eocene to Miocene age. According to BP (2000) internal report of the Bougainville-1 well summary in the Deepwater Tarakan Basin, there was poor hydrocarbon shows with minor gas peaks only. The section below detachment possibly mature source rock but no migration path to charge to the anticline (BP, 2000). Thus, the Bougainville-1 well is considered as dry well and it is interpreted that the well was drilled far down dip of the crest of the anticline structure and below the hydrocarbon water contacts (Atzeni and Guritno, 2003).

However, the Aster-1 well in the Deepwater Tarakan Basin shows promising result. According to Atzeni and Guritno (2003), the Aster-1 well, which was situated relatively near the crestal position of the anticline structure, consists of 6 oil and gas levels with the main discovery level was the Upper Miocene AST200 that has $10 \mathrm{~m}$ of oil. The biomarkers of the oil sample show a terrestrial origin of the source rock generated the oil (Atzeni and Guritno, 2003). The oil and gas discovery from Aster-1 well indicates the effectiveness of the petroleum system in the Deepwater Tarakan Basin (Atzeni and Guritno, 2003).

\subsection{Reservoir}

Oligo-Miocene carbonate in the Muara Sub-basin has been targeted as a potential reservoir (Achmad and Samuel, 1984; Lentini and Darman, 1996; PERTAMINA-BPPKA, 1996; Wilson et al., 1999; Wilson and Evans, 2002; Wilson et al., 2007). Oil and gas shows have been encountered from this carbonate reservoir 
as shown in several exploration wells (Taballar-1, Karang Besar-1, and Segitiga-1) reported by previous authors (Achmad and Samuel, 1984; Lentini and Darman, 1996; PERTAMINA-BPPKA, 1996).

Average porosity from the wells drilled in the Muara Sub-basin range from $12 \%$ in Taballar- 1 well up to about 22\% in Karang Besar-1 well (PERTAMINA-BPPKA, 1996). Another potential reservoir in the Muara Sub-basin is deep marine sandstones of Late Oligocene and Miocene age. Other possibilities are Miocene shallow marine sandstones in the landward area. However, in the Muara Sub-basin, the shallow water area was mostly covered by carbonate during the Oligo-Miocene (PERTAMINA-BPPKA, 1996).

In the Tarakan Basin, oil and gas has mainly been produced from Miocene sandstones of the Tabul Formation (Achmad and Samuel, 1984; Lentini and Darman, 1996; PERTAMINA-BPPKA, 1996) which were primary objectives for the establishment of production at the Sembakung Field (25 MMBO) in 1976 by Arco (Lentini and Darman, 1996). However, little exploration has occurred in the Deepwater Tarakan Basin.

Potential reservoirs in the Deepwater Tarakan Basin include Oligo-Miocene deep marine sandstones. Quartz turbidite sandstones with almost 90\% quartz encountered in the Celebes Sea was transported from the Borneo to the deep marine areas in the east during the Middle-Late Miocene (Nichols and Hall, 1999). Quartz-rich sandstones are usually mature sandstones with good reservoir quality. Direct Hydrocarbon Indicators (DHI) in the Deepwater Tarakan Basin suggest several potential gas-bearing formations containing biogenic shallow gas (Figure 22). Furthermore, several DHI resemble Bottom Stimulating Reflectors (BSR) generated from methane hydrates.

The reservoir summary from Bougainville-1 well indicates 280m thick Miocene sandstone with individual thickness of 0.3-23m (with average $\sim 2.5 \mathrm{~m}$ thick; BP, 2000). It has medium grey sandstones, fine grained, well sorted, sub-angular to rounded grain, loose-friable, 20-30\% porosity, which has deposited in the overbank to channel levee complex (BP, 2000). Similarly, Atzeni and Guritno (2003) reported the Miocene sandstone drilled from the Aster-1 well has dark-grey sandstone, very fine to medium grained, sub-rounded, poorly sorted, poor visible porosity, occasionally good to excellent infer porosity, and 
17m gas; Atzeni and Guritno, 2003). It is interpreted that the depositional environment of Miocene sandstone in the Aster-1 well was drilled in the submarine mid-lower slope setting, whilst the in the Bougainville-1 well penetrated a more distal environment of basinal area (Atzeni and Guritno, 2003).

\subsection{Potential trap and seal}

In the Muara Sub-basin, the potential traps are mainly stratigraphic traps. Pinch out stratigraphic trapping geometries mainly occur in Oligo-Miocene marine sandstones isolated by the marine shales as a seal. Potential depositional relief traps also occur in the Oligocene carbonates sealed by shale and locally by tight Miocene carbonates.

Observation in the Deepwater Tarakan Basin indicate several potential stratigraphic and structural traps. Anticline structures could provide 4-way dip closure with localized pinch outs of Oligo-Miocene deep marine sandstones are likely trapping systems. In the basinward area, the net to gross of sand to shale is likely to decrease. Thus, sealing effectiveness could be an issue.

\subsection{Risk and uncertainty}

The primary risk in the Muara Sub-basin is the sealing capacity. Poorly lateral continuity of shales leads to increased uncertainty. Fault sealing may also be a problem. Evidence from several seismic sections showing Direct Hydrocarbon Indicators (DHI) indicates gas leakages utilizing normal faults to the younger unit above. Gas escape is interpreted from the Oligocene carbonate unit (Figure 23). This indication could increase the uncertainty of hydrocarbon accumulation.

In the Deepwater Tarakan Basin, the primary risk is the hydrocarbon charging (source rock maturation, generation, and migration timing of the hydrocarbon). For example, if the generation post-dates the toethrust faults, there would be a good trapping system for hydrocarbons. On the other hand, if the timing of hydrocarbon generation pre-dates the thrust faults, the trapping system would be broken and allow leaking of hydrocarbons. Again, this will increase the uncertainty of hydrocarbon accumulation. 
- There are eight main reflector packages identified in the Muara Sub-basin, i.e.: Unit X (Middle Eocene and older basement complex); Unit A (Upper Eocene marine siliciclastic); Unit B (Lower Oligocene carbonates); Unit C (Upper Oligocene marine mudstones); Unit D, Unit E, Unit F, and Unit G are Lower Miocene-Recent marine sediments.

- Six main reflector packages are identified in the Deepwater Tarakan Basin, i.e.: Unit X1 (Eocene basaltic basement equivalent); Unit C1, Unit D1, Unit E1, Unit F1, and Unit G1 are Eocene-Recent

792

- Two main reflector packages are identified in the North Sulawesi Fold-Thrust Belt, as Upper Unit and Lower Unit that possibly equivalent with Pleistocene and older formation respectively.

- There is no continuation of Palu-Koro strike-slip Fault to the Muara Sub-basin and the adjacent area which was interpreted by previous authors as formed by a transpressional fault system. The NW-SE structural trend in the Muara Sub-basin (i.e. Maratua Ridge) is an Eocene transform fault active

800

801 during spreading of the Celebes Sea which became inactive from the Early Oligocene.

- Inversion and uplift since Middle Miocene in Borneo led to development of rapidly prograding deltaic environments in the Muara Sub-basin and Deepwater Tarakan Basin. During the latest Miocene or Pliocene, loading of the upper part of the prograding delta to the east of the Tarakan Basin caused development of gravity tectonics in the Deepwater Tarakan Basin.

- The North Sulawesi Fold-Thrust Belt developed since the latest Miocene or Pliocene associated with subduction of Celebes Sea beneath North Arm of Sulawesi. The downflexing of Celebes Sea as a result 
- During the Pliocene, the Deepwater Tarakan Basin and Muara Sub-basin were dominated by sedimentation in the prograding delta and the basin as inversion and uplift continued. Gravity tectonics in the Deepwater Tarakan Basin were not active since Pleistocene.

- Potential hydrocarbon plays identified within the Muara Sub-basin include an Oligocene carbonate play and an Oligocene-Miocene shallow to deep marine sandstones play. In the Deepwater Tarakan Basin, the main potential is an Oligocene-Miocene deep marine sandstone play. Sealing effectiveness

\section{ACKNOWLEDGEMENTS}

The first author would like to thank the SE Asia Research Group (SEARG) for the scholarship opportunity during the MSc and for continued support during the final project. SEARG is funded by consortium of oil companies. We are grateful to PGS for the generous provision of 2D seismic data and GeoData Ventures Pte Ltd for the multibeam bathymetry data under an academic license agreement. We would also like to thank The KINGDOM Software 8.8 as the main software that used in this project.

\section{REFERENCES}

ACHMAD, Z. \& SAMUEL, L. Stratigraphy and depositional cycles in the NE Kalimantan Basin. 13th Annual Convention 1984 Jakarta. Proceedings, Indonesian Petroleum Association, 12 pp.

ADVOKAAT, E. L. 2015. Neogene extension and exhumation in NW Sulawesi. Unpublished Ph.D. Thesis, Royal Holloway University of London.

ADVOKAAT, E. L., HALL, R., WHITE, L. T., WATKINSON, I. M., RUDYAWAN, A. \& BOUDAGHER-FADEL, M. K. 2017. Miocene to recent extension in NW Sulawesi, Indonesia. Journal of Asian Earth Science.

ATZENI, G. L. \& GURITNO, E. 2003. Aster-1 Final Geological Report. ENI Bukat.

BELLIER, O., SEBRIER, M., SEWARD, D., BEAUDOUIN, T., VILLENEUVE, M. \& PUTRANTO, E. 2006. Fission track and fault kinematics analyses for new insight into the Late Cenozoic tectonic regime changes in West-Central Sulawesi (Indonesia). Tectonophysics, 413, 201-220.

BP 2000. Bougainville-1 Ambalat PSC, Deepwater Tarakan Basin - Makassar Strait, Indonesia. Shell-BPLasmo-Unocal.

CAMP, W. K., GURITNO, E. E., DRAJAT, D. \& WILSON, M. E. Middle-lower Eocene turbidites: a new deepwater play concept, Kutei Basin, East Kalimantan, Indonesia. 33rd Annual Convention 2009 Jakarta. Proceedings, Indonesian Petroleum Association, $14 \mathrm{pp}$.

CHAMBERS, J. \& DALEY, T. E. 1997. A tectonic model for the onshore Kutai Basin, East Kalimantan. In: Fraser, A. J., Matthews, S. J., Murphy, R. W., (Eds), Petroleum Geology of Southeast Asia, 126.

CHUNG-HWA, P., TAMAKI, K. \& KOBAYASHI, K. 1990. Age-depth correlation of the Philippine Sea back-arc basins and other marginal basins in the world. Tectonophysics, 181, 351-371. 
CLOKE, I., MILSOM, J. \& BLUNDELL, D. 1999a. Implications of gravity data from East Kalimantan and the Makassar Straits: a solution to the origin of the Makassar Straits? Journal of Asian Earth Sciences, 17, 61-78.

CLOKE, I., MOSS, S. \& CRAIG, J. 1999b. Structural controls on the evolution of the Kutai Basin, East Kalimantan. Journal of Asian Earth Sciences, 17, 137-156.

DALY, M. C., COOPER, M. A., HOOPER, B. G. D., WILSON, I. \& SMITH, D. G. 19991. Cenozoic plate tectonics and basin evolution in Indonesia. Marine and Petroleum Geology, 8.

DJAJADIHARDJA, Y. S., TAIRA, A., TOKUYAMA, H., AOIKE, K., REICHERT, C., BLOCK, M., SCHLUTER, H. U. \& NEBEN, S. 2004. Evolution of an accretionary complex along the north arm of the island of Sulawesi, Indonesia. Island Arc, 13, 1-17.

FRASER, T. H., JACKSON, B. A., BARBER, P. M., BAILLIE, P. \& MYERS, K. The West Sulawesi Fold Belt and Other New Plays Within the North Makassar Straits-A Prospectivity Review. 29th Annual Convention 2003 Jakarta. Proceedings, Indonesian Petroleum Association, 19 pp.

GAFEIRA, J. 2010. A geomorphological interpretation of multibeam data from the nearshore area between Belfast Lough and Cushendun, Northern Ireland. Marine Geoscience Programme Commisioned Report CR/10/075. British Geological Survey Commisioned Report.

GOVERS, R. \& WORTEL, M. J. 2005. Lithosphere tearing at STEP faults: response to edges of subduction zones. Earth and Planetary Science Letters, 236, 505-523.

HALL, R. 1996. Reconstructing Cenozoic SE Asia. Geological Society, London, Special Publications, 106, 153-184.

HALL, R. 2002. Cenozoic geological and plate tectonic evolution of SE Asia and the SW Pacific: computerbased reconstructions, model and animations. Journal of Asian Earth Sciences, 20, 353-431.

HALL, R. 2011. Australia-SE Asia collision: plate tectonics and crustal flow. Geological Society, London, Special Publications, 355, 75-109.

HALL, R. 2012. Late Jurassic-Cenozoic reconstructions of the Indonesian region and the Indian Ocean. Tectonophysics, 570, 1-41.

HALL, R., CLOKE, I. R., NUR'AINI, S., PUSPITA, S. D., CALVERT, S. J. \& ELDERS, C. F. 2009. The North Makassar Straits: what lies beneath? Petroleum Geoscience, 15, 147-158.

HAMILTON, W. B. 1979. Tectonics of the Indonesian region, US Govt. Print. Off.

HAQ, B. U., HARDENBOL, J. \& VAIL, P. R. 1988. Mesozoic and Cenozoic chronostratigraphy and cycles of sea-level change.

HIDAYATI, S., GURITNO, E., ARGENTON, A., ZIZA, W. \& CAMPANA, I. D. 2007. Re-visited structural framework of the Tarakan sub-basin Northeast Kalimantan - Indonesia. Indonesian Petroleum Association, Proceedings 31st Annual Convention, 255-272.

ICS. 2017. International Chronostratigraphic Chart [Online]. International Commission on Stratigraphy. Available: http://www.stratigraphy.org/index.php/ics-chart-timescale [Accessed May 15th 2017].

LENTINI, M. R. \& DARMAN, H. Aspects of the Neogene tectonic history and hydrocarbon geology of the Tarakan Basin. 27th Annual Convention, 1996 Jakarta. Proceedings, Indonesian Petroleum Association, $11 \mathrm{pp}$.

LETOUZEY, J., WERNER, P. \& MARTY, A. 1990. Fault reactivation and structural inversion. Backarc and intraplate compressive deformations. Example of the eastern Sunda shelf (Indonesia). Tectonophysics, 183, 341-362.

MITCHUM JR, R., VAIL, P. \& THOMPSON III, S. 1977. Seismic stratigraphy and global changes of sea level: Part 2. The depositional sequence as a basic unit for stratigraphic analysis: Section 2. Application of seismic reflection configuration to stratigraphic interpretation.

MORLEY, C. K., KING, R., HILLIS, R., TINGAY, M. \& BACKE, G. 2011. Deepwater fold and thrust belt classification, tectonics, structure and hydrocarbon prospectivity: A review. Earth-Science Reviews, 104, 41-91.

MURAUCHI, S., LUDWIG, W., DEN, N., HOTTA, H., ASANUMA, T., YOSHII, T., KUBOTERA, A. \& HAGIWARA, K. 1973. Structure of the Sulu Sea and the Celebes Sea. Journal of Geophysical Research, 78, 34373447.

NICHOLS, G. \& HALL, R. 1999. History of the Celebes Sea Basin based on its stratigraphic and sedimentological record. Journal of Asian Earth Sciences, 17, 47-59.

NUR'AINI, S., HALL, R. \& ELDERS, C. F. Basement Architecture and Sedimentary Fill of the North Makassar Straits Basin. 30th Annual Convention, 2005 Jakarta. Proceedings, Indonesian Petroleum Association, $14 \mathrm{pp}$. 
ORANGE, D. L., TEAS, P. A. \& DECKER, J. SS: Multibeam Backscatter-Insights into Marine Geological Processes and Hydrocarbon Seepage. Offshore Technology Conference, 2010. Offshore Technology Conference Houston, Texas, USA, OTC 20860 1-22.

PERTAMINA-BPPKA 1996. Petroleum geology of Indonesian Basins: principles, methods, and application, Jakarta, Pertamina BPPKA (Foreign Contractors Ventures Development Body).

PIETERS, P. E., PIGRAM, C. J., TRAIL, D. S., DOW, D. B., RATMAN, N. \& SUKAMTO, R. 1983. The stratigraphy of western Iran Jaya. Bulletin of the Geological Research and Development Centre, 8, 14-48.

PUTRA, P. R., SAPIIE, B. \& RAMDHAN, A. M. 2018. PS Relationship Between Pore Pressure and Structural Model in "Passive Margin" Offshore Tarakan Sub-Basin, Northeast Kalimantan, Indonesia.

RANGIN, C., SILVER, E. A., VON BREYMAN, M. T. \& AL., E. 1990. Proceedings of the Ocean Drilling Program. Initial Reports.

RUDYAWAN, A. 2016. Neogene stratigraphy, structure, and magmatism of the central North Arm of Sulawesi, Indonesia. Unplublished Ph.D. Thesis, Royal Holloway University of London.

SATYANA, A. H., NUGROHO, D. \& SURANTOKO, I. 1999. Tectonic controls on the hydrocarbon habitats of the Barito, Kutei, and Tarakan Basins, Eastern Kalimantan, Indonesia: major dissimilarities in adjoining basins. Journal of Asian Earth Sciences, 17, 99-122.

SILVER, E. A., MCCAFFREY, R. \& SMITH, R. B. 1983. Collision, rotation, and the initiation of subduction in the evolution of Sulawesi, Indonesia. Journal of Geophysical Research: Solid Earth, 88, 9407-9418.

SILVER, E. A. \& RANGIN, C. 1. LEG 124 Tectonic synthesis. Proceedings of the Ocean Drilling Program, Scientific Results, 1991. 3-9.

SOCQUET, A., VIGNY, C., CHAMOT-ROOKE, N., SIMONS, W., RANGIN, C. \& AMBROSIUS, B. 2006. India and Sunda plates motion and deformation along their boundary in Myanmar determined by GPS. Journal of Geophysical Research: Solid Earth, 111.

SUNARYO, R., MARTODJOJO, S. \& WAHAB, A. 1988. Detailed geological evaluation of the hydrocarbon prospects in the Bungalun area, East Kalimantan. Indonesian Petroleum Association, Proceedings 17th annual convention, Jakarta, 1988, I, 423-446.

SURMONT, J., LAJ, C., KISSEL, C., RANGIN, C., BELLON, H. \& PRIADI, B. 1994. New paleomagnetic constraints on the Cenozoic tectonic evolution of the North Arm of Sulawesi, Indonesia. Earth and Planetary Science Letters, 121, 629-638.

VIGNY, C., PERFETTINI, H., WALPERSDORF, A., LEMOINE, A., SIMONS, W., VAN LOON, D., AMBROSIUS, B., STEVENS, C., MCCAFFREY, R. \& MORGAN, P. 2002. Migration of seismicity and earthquake interactions monitored by GPS in SE Asia triple junction: Sulawesi, Indonesia. Journal of Geophysical Research: Solid Earth, 107.

WALPERSDORF, A., RANGIN, C. \& VIGNY, C. 1998. GPS compared to long-term geologic motion of the north arm of Sulawesi. Earth and Planetary Science Letters, 159, 47-55.

WATKINSON, I. M. 2011. Ductile flow in the metamorphic rocks of central Sulawesi. In: HALL, R., COTTAM, M. A. \& WILSON, M. E. J. (eds.) The SE Asian Gateway: History and Tectonics of the Australia-Asia collision.

WATKINSON, I. M. \& HALL, R. 2016. Fault systems of the eastern Indonesian triple junction: evaluation of Quaternary activity and implications for seismic hazards. Geological Society, London, Special Publications, 441, SP441. 8.

WEISSEL, J. K. 1980. Evidence for Eocene oceanic crust in the Celebes Basin. The Tectonic and Geologic Evolution of Southeast Asian Seas and Islands, 37-47.

WIGHT, A., HARE, L. \& REYNOLDS, J. 1992. Tarakan Basin, NE Kalimantan, Indonesia: a century of exploration and future potential. Bulletin of the Geological Society of Malaysia, 33, 265-288.

WILSON, M., CHAMBERS, J., EVANS, M., MOSS, S. \& NAS, D. S. 1999. Cenozoic carbonates in Borneo: case studies from northeast Kalimantan. Journal of Asian Earth Sciences, 17, 183-201.

WILSON, M. E. \& EVANS, M. J. 2002. Sedimentology and diagenesis of Tertiary carbonates on the Mangkalihat Peninsula, Borneo: implications for subsurface reservoir quality. Marine and Petroleum Geology, 19, 873-900.

WILSON, M. E., EVANS, M. J., OXTOBY, N. H., NAS, D. S., DONNELLY, T. \& THIRLWALL, M. 2007. Reservoir quality, textural evolution, and origin of fault-associated dolomites. AAPG bulletin, 91, 1247-1272. 


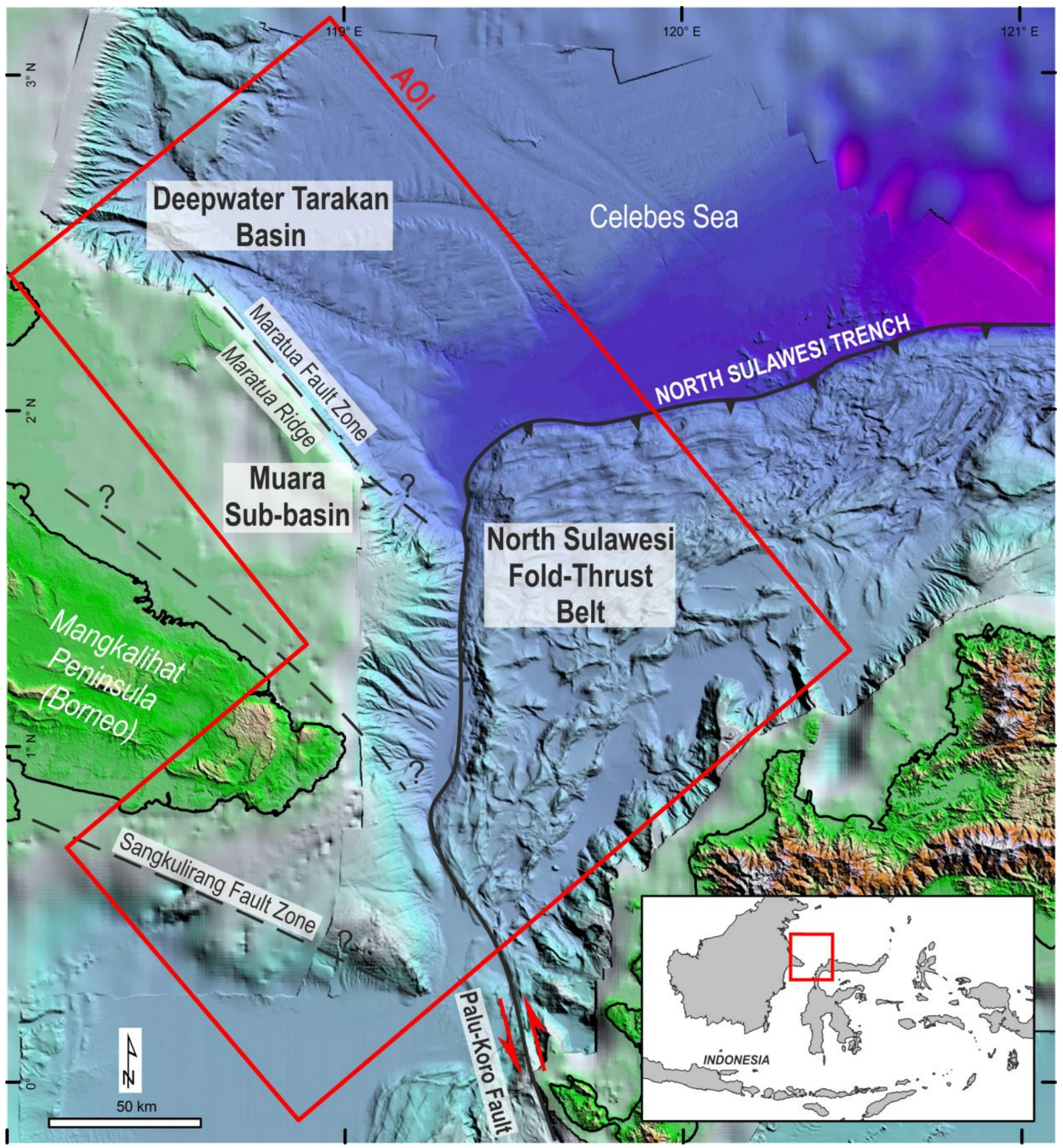

Figure 1. ASTER DEM, bathymetry, and gravity image of study area showing topography, regions, basin or sub-basin, and major tectonic province (Advokaat, 2015; Camp et al., 2009; Cloke et al., 1999b). Red box highlighting the area of interest (AOI). 


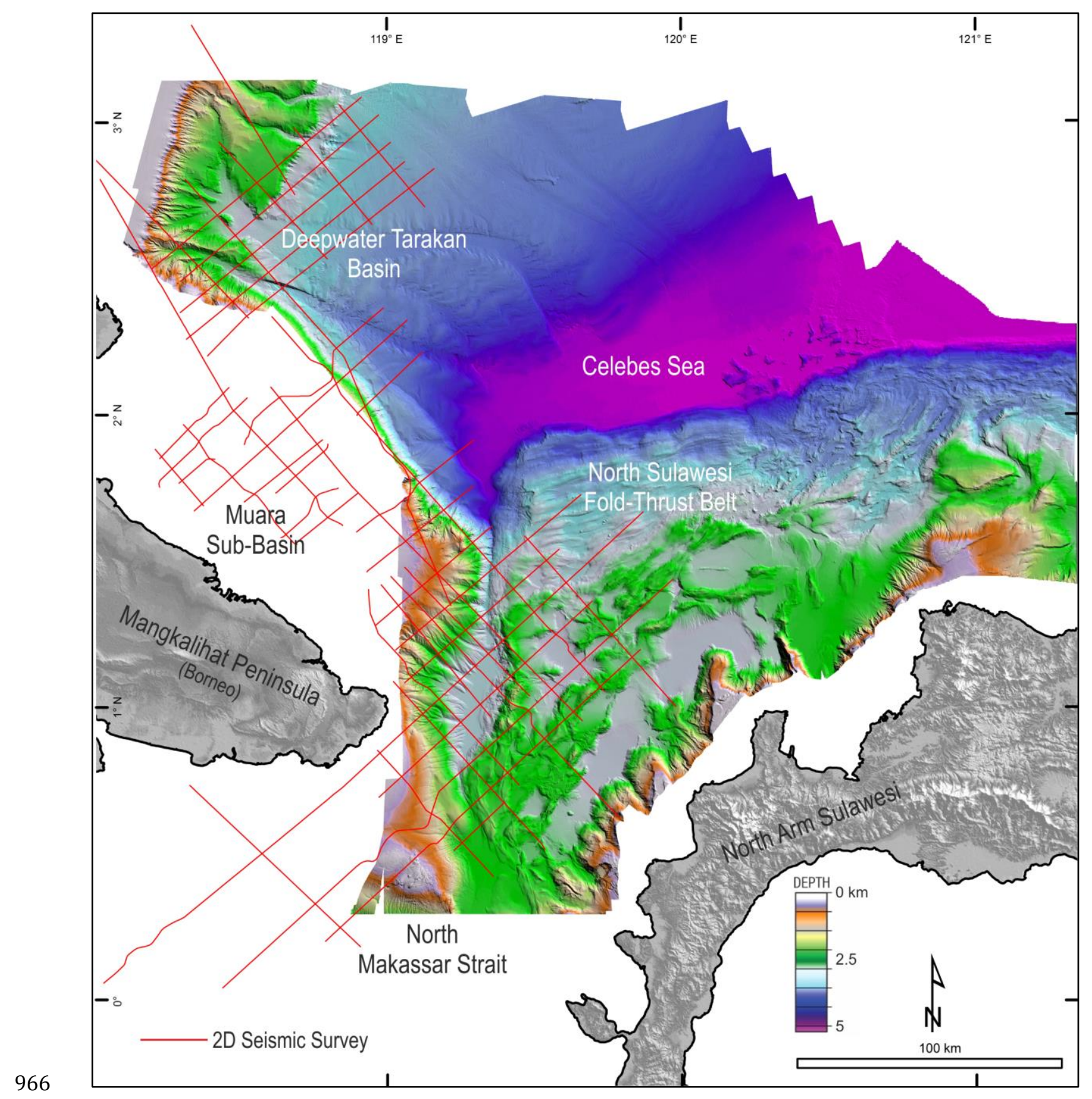

967 Figure 2. DEM on land from SRTM (Shuttle Radar Topographic Mission) with the multibeam bathymetry

968 map and 2D seismic survey lines used in this study. 


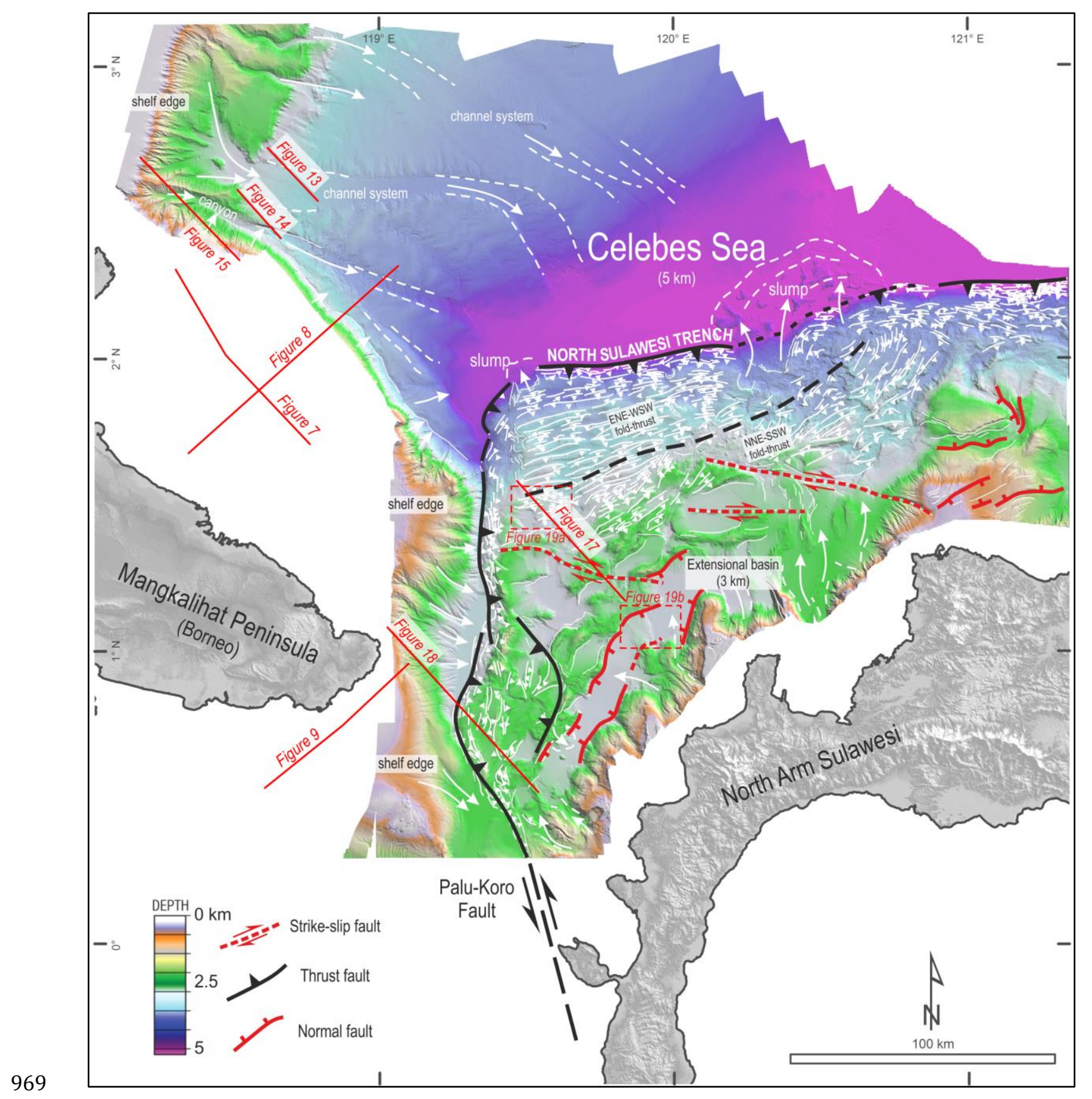

970 Figure 3. Combined DEM from SRTM map with a shaded-relief map of interpreted multibeam bathymetry

971 with exceptional details of sedimentary and structural features described in this chapter. Red lines

972 indicate seismic section presented in this paper. Illumination direction from NE. 


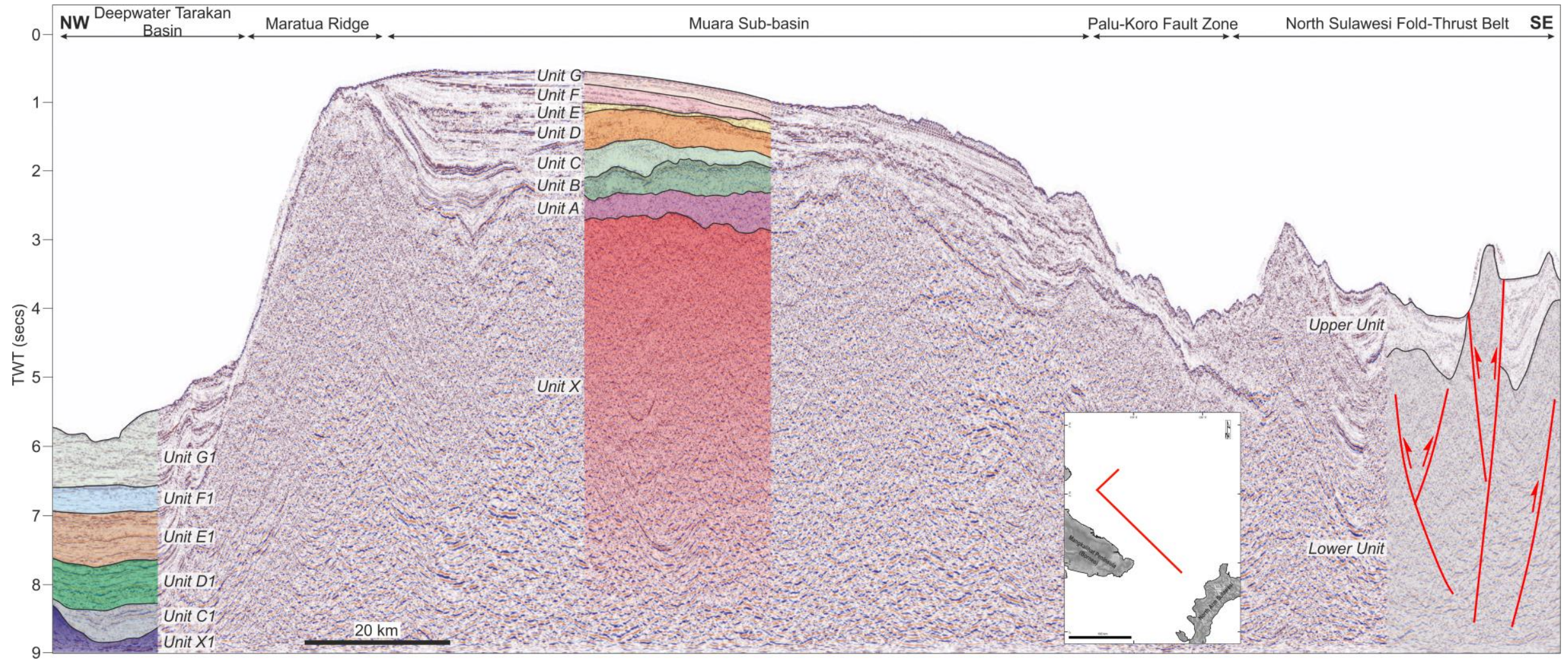

975 Figure 4. Composite seismic line across Deepwater Tarakan Basin, Muara Sub-basin, and North Sulawesi Fold-Thrust Belt showing different seismic stratigraphic 
Karang Besar-1

(after Sunaryo et al., 1988)

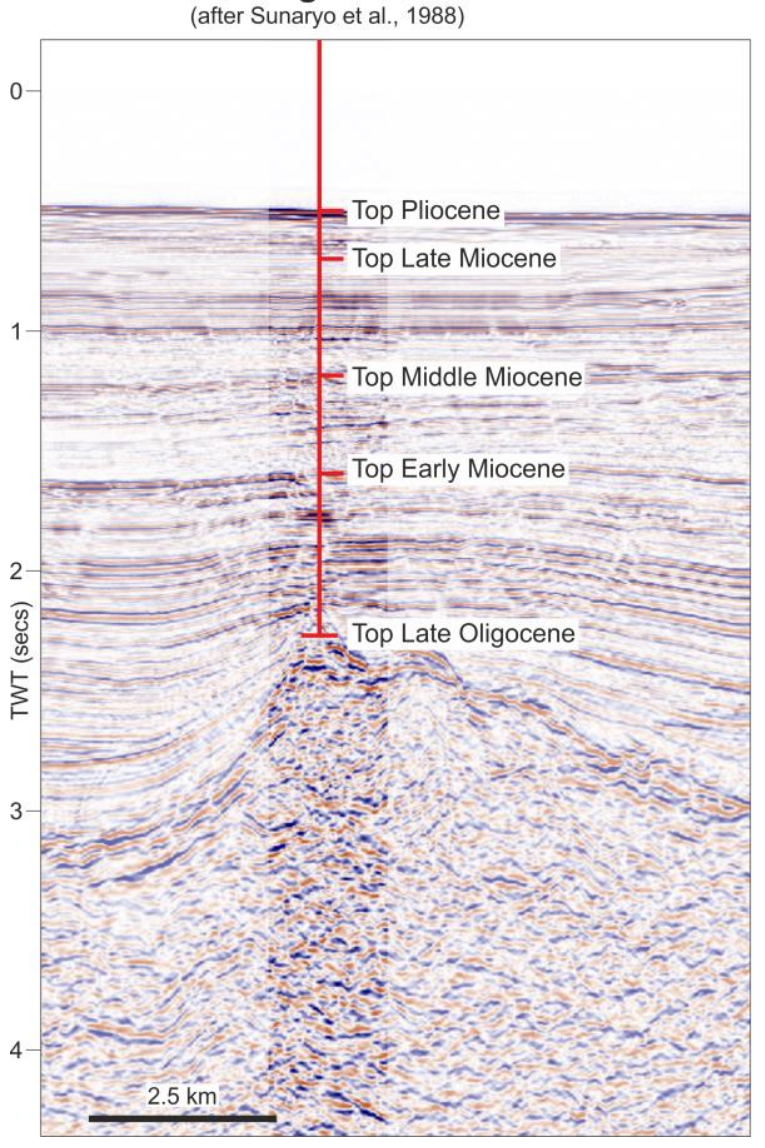

Makassar-A1

(after Camp et al., 2009)

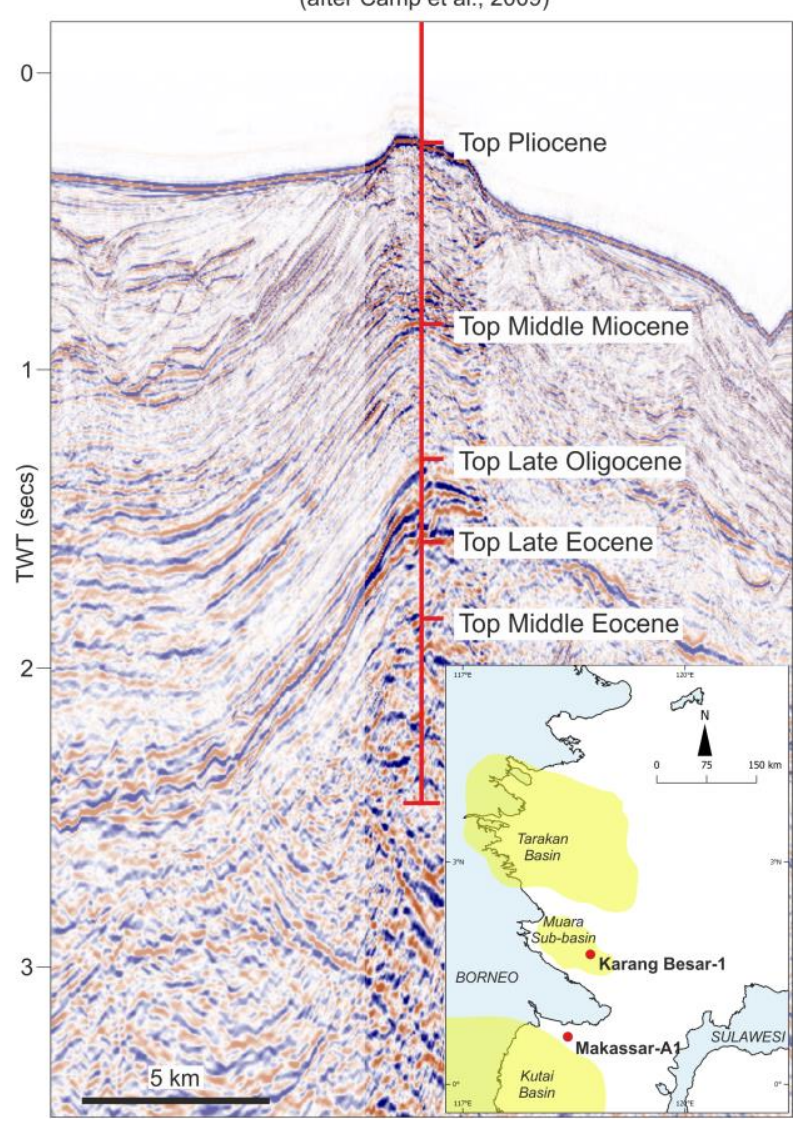

978 Figure 5. Stratigraphic well control used in this paper for the Muara Sub-basin (modified after Camp et al.,

979 2009; Sunaryo et al., 1988). 


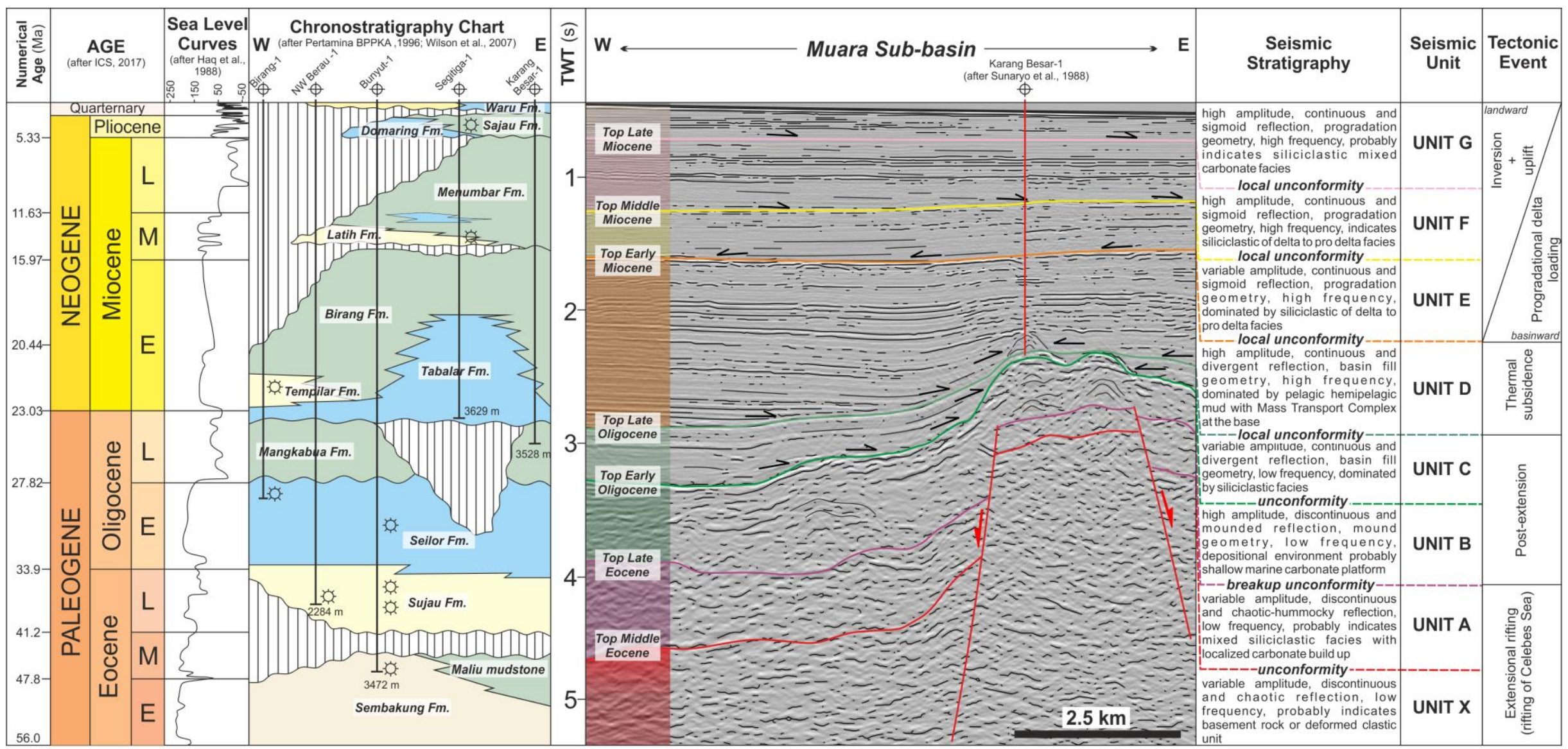

Wilson et al., 2007; Sunaryo et al., 1988). 


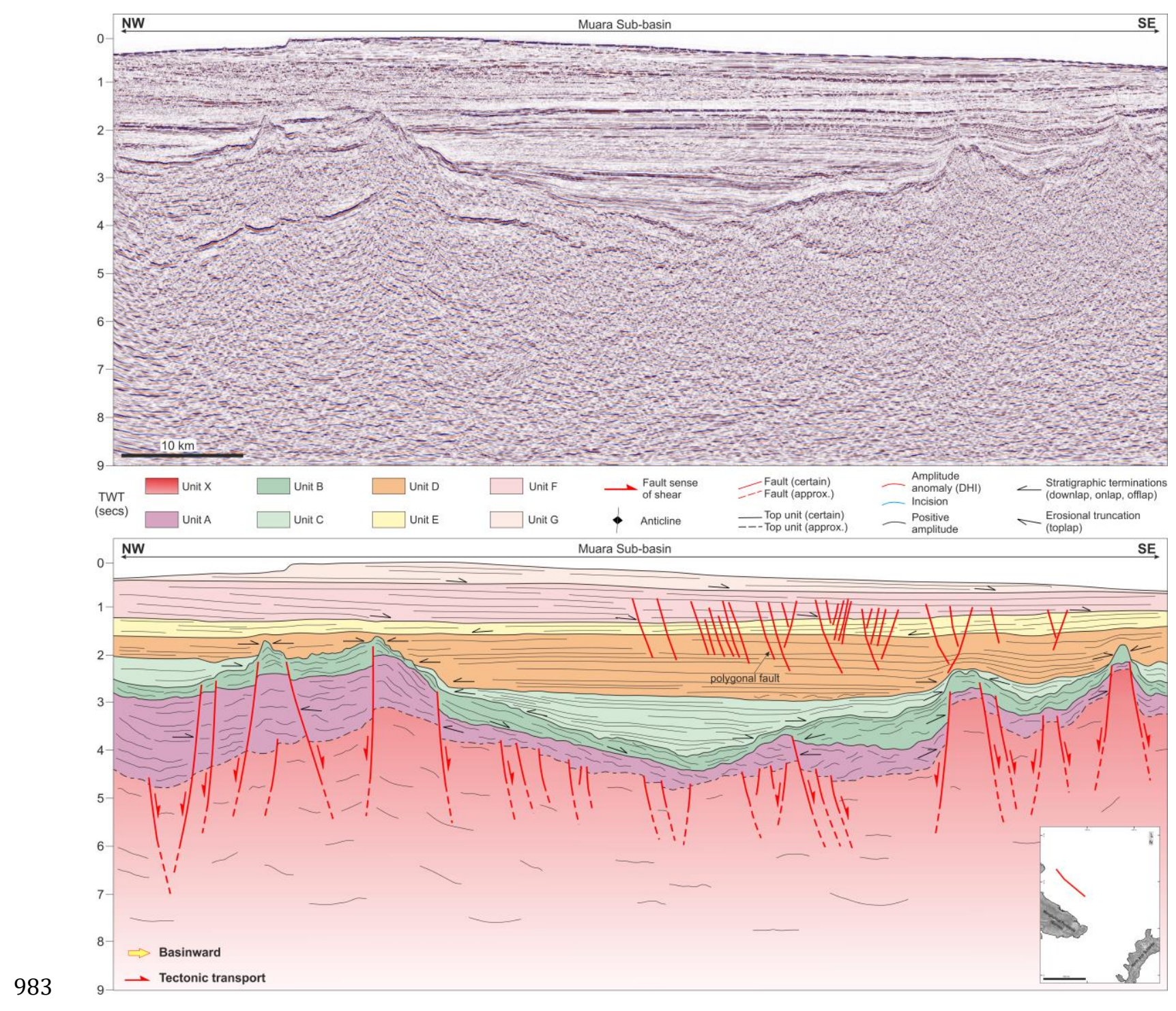

984 Figure 7. Uninterpreted (above) and interpreted (below) NW-SE seismic section following approximately

985 the axis of Muara Sub-basin. The basin geometry is strongly controlled by the underlying basement

986 configuration (Unit X). Carbonate build-up features in Unit B were seated on top of structural high and

987 buried by young sedimentary strata. 

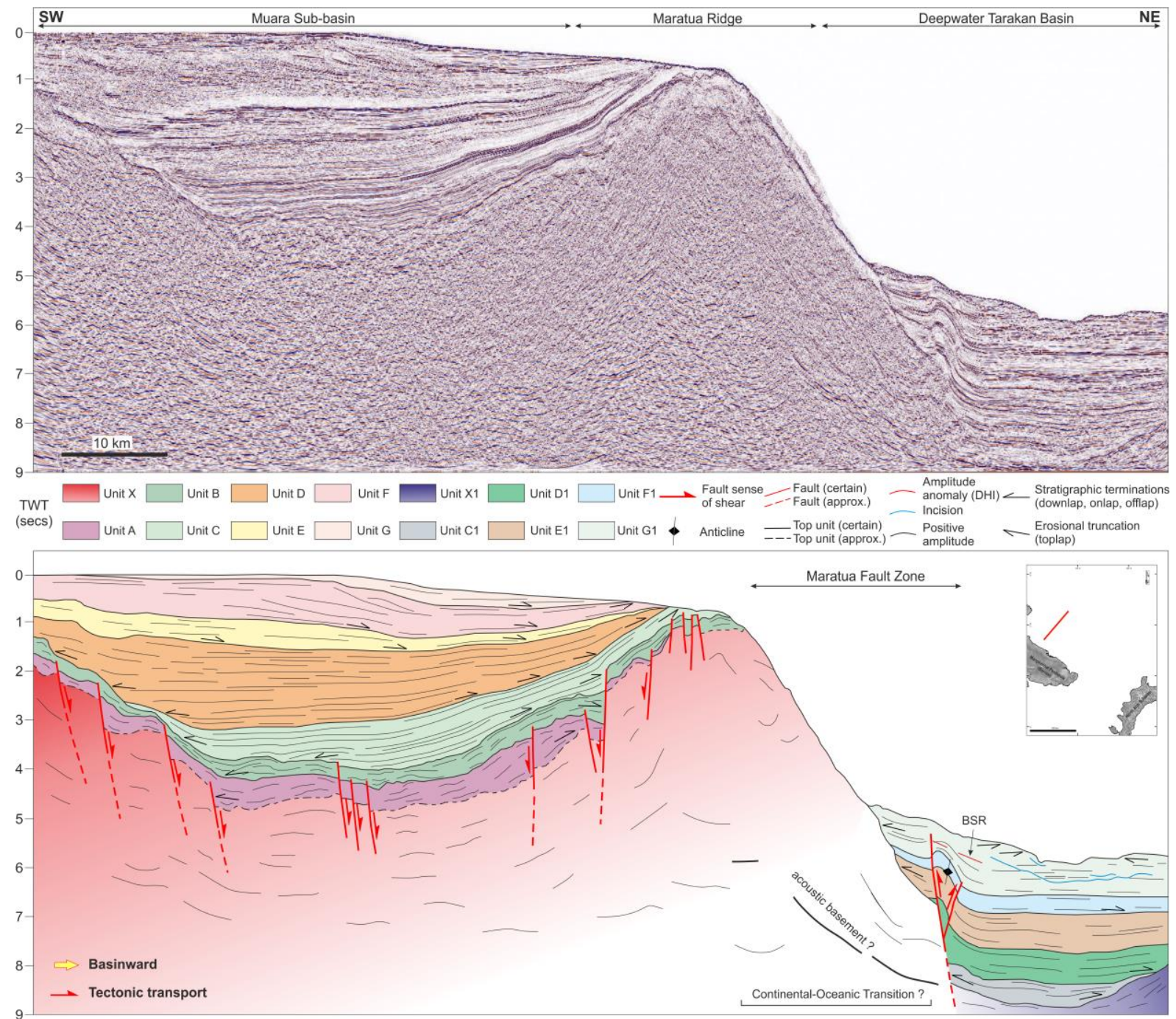

989 Figure 8. Uninterpreted (above) and interpreted (below) NE-SW seismic section through Muara Sub-

990 basin, Maratua Ridge, and Deepwater Tarakan Basin. The great amount of sediment thicknesses in the

991 Muara Sub-basin were deposited since Early Miocene following subsidence and rapid sedimentation in

992 such narrow basin. The sediment in the Deepwater Tarakan Basin is separated to the Muara Sub-basin by

993 Maratua Ridge as prominent structural high. 



Figure 9. Uninterpreted (above) and interpreted (below) NE-SW seismic section from the eastern end of

996 Mangkalihat High. Inverted extensional fault were observed from the seismic section where the inversion

997 event is interpreted to have occur since Middle Miocene as shown by erosional truncation at Top Unit E

998 (Top Middle Miocene) as a result of Mangkalihat uplift. These also contributes to the prograding shelf in

999 the Muara Sub-basin as observed at seismic stratigraphy Unit E, F, and G shown in Figure 8. 

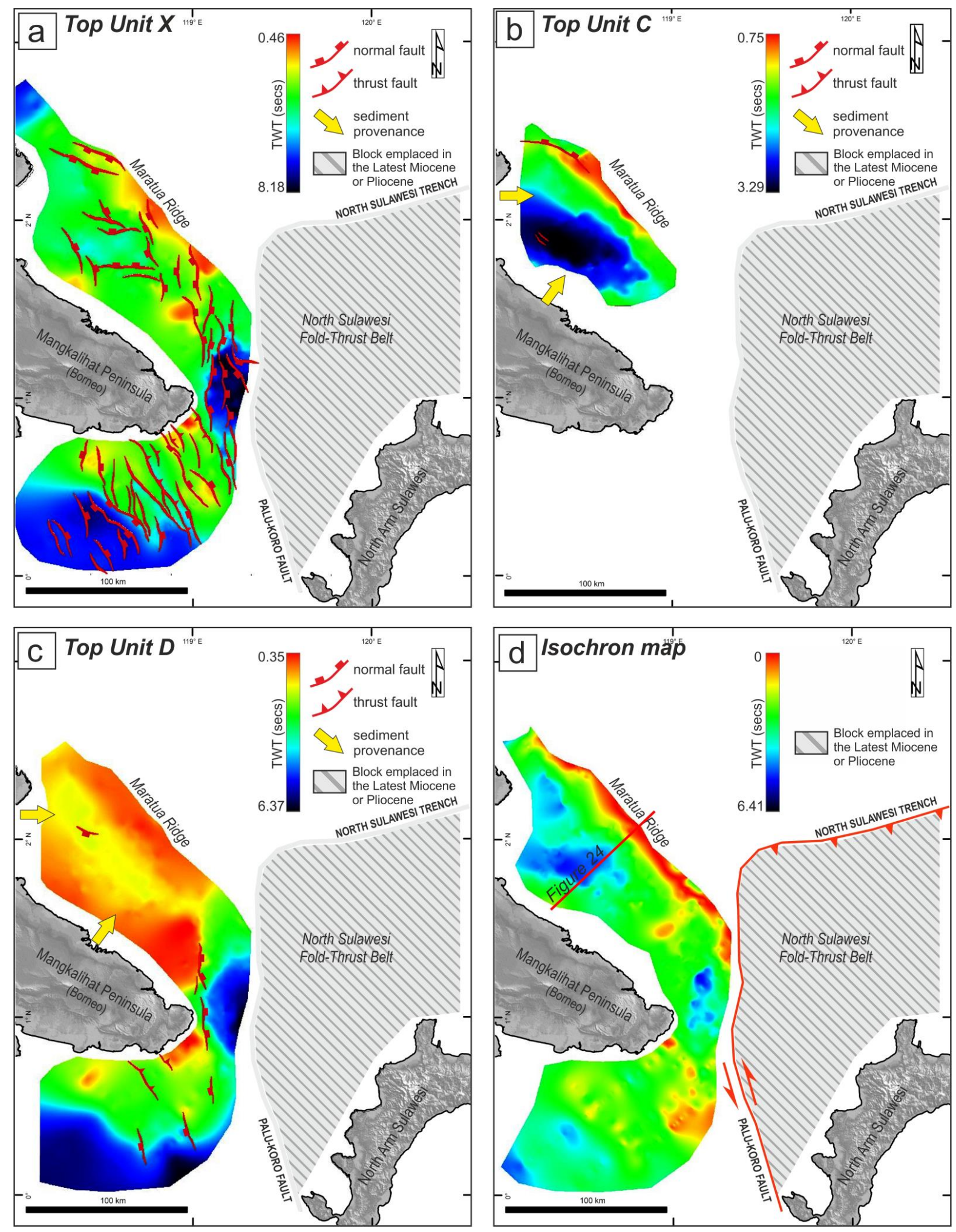

Figure 10. Subsurface map in the Muara Sub-basin and adjacent area. (a) Depth to Top Unit X structure

map highlights basal unconformity in the Muara Sub-basin were controlled by broadly NNW-SSE

structural trend. Minor thrust faults were observed in the eastern most of Mangkalihat Peninsula as inverted normal fault which also seen from the seismic profile. (b) Local infilled of Unit C in the Muara Sub-basin following the post-extension in the area. (c) Widespread deposition of Unit D during Early 
1006 Miocene with not much deformation in the Muara Sub-basin. (d) Total sediment thickness map showing 1007 the NW-SE trend of the axial Muara Sub-basin.

1008 


\section{Bougainville-1}

(after BP, 2000; unpublished manuscript)

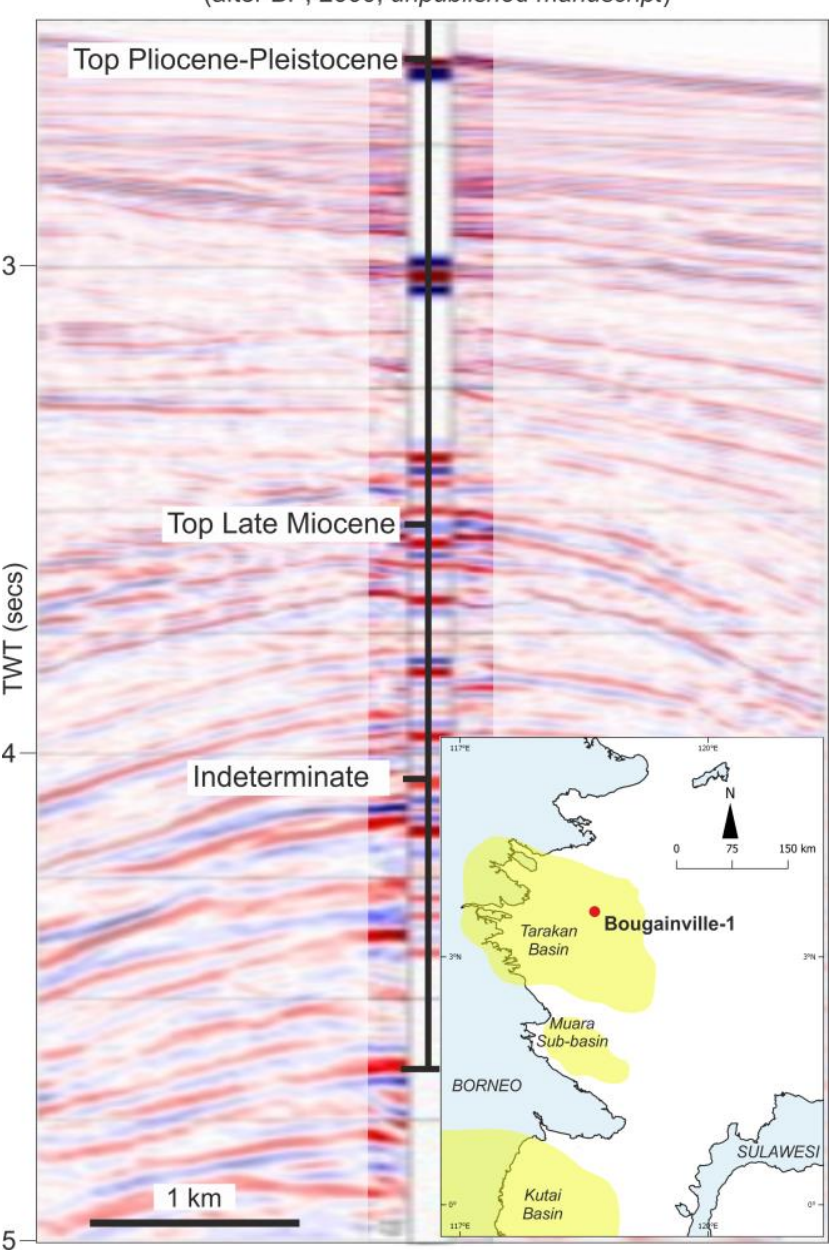

1010 Figure 11. Stratigraphic well control used in this paper for the Deepwater Tarakan Basin (modified after 1011 BP, 2000). 


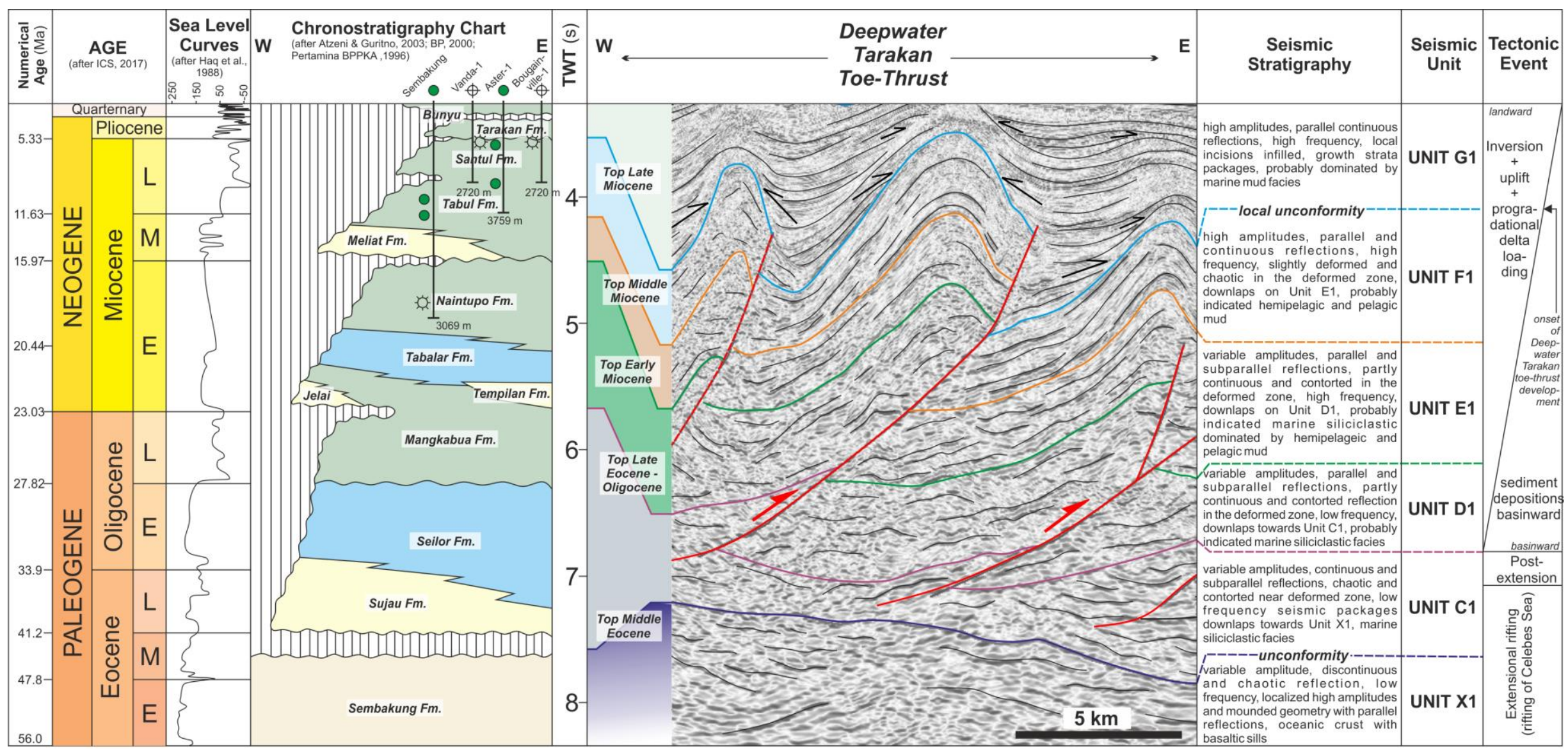

1013 Figure 12. Summarized seismic stratigraphy units of the Deepwater Tarakan Basin modified from various sources (Atzeni and Guritno, 2003; BP, 2000; Haq et al., 


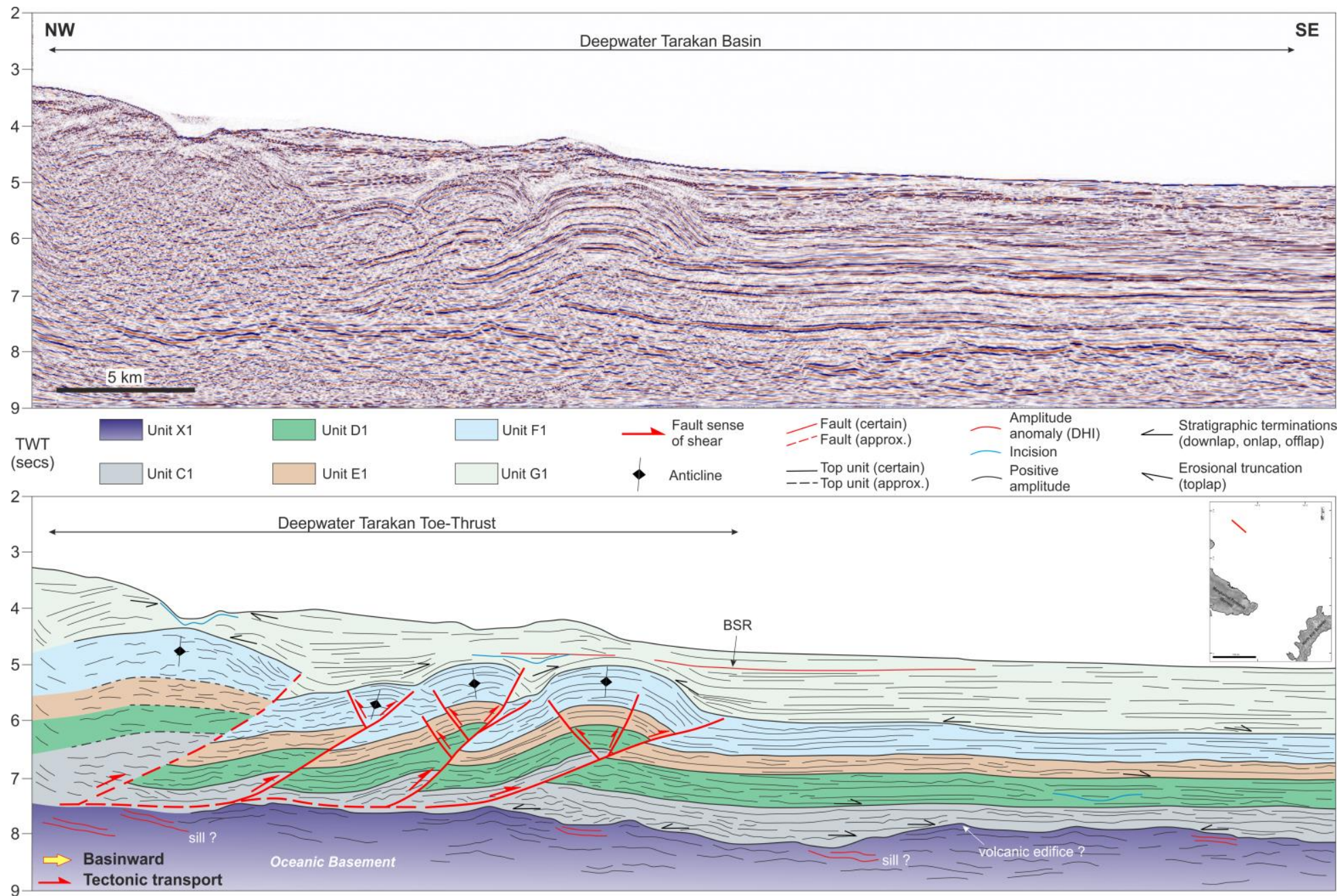

1016 Figure 13. Uninterpreted (above) and interpreted (below) NW-SE seismic section from Deepwater Tarakan Basin exhibit deformed strata in the contractional

1017 structural province which formed the Deepwater Tarakan Toe-Thrust and detached within the Unit C1. The toe-thrust deformation younging direction is to the 


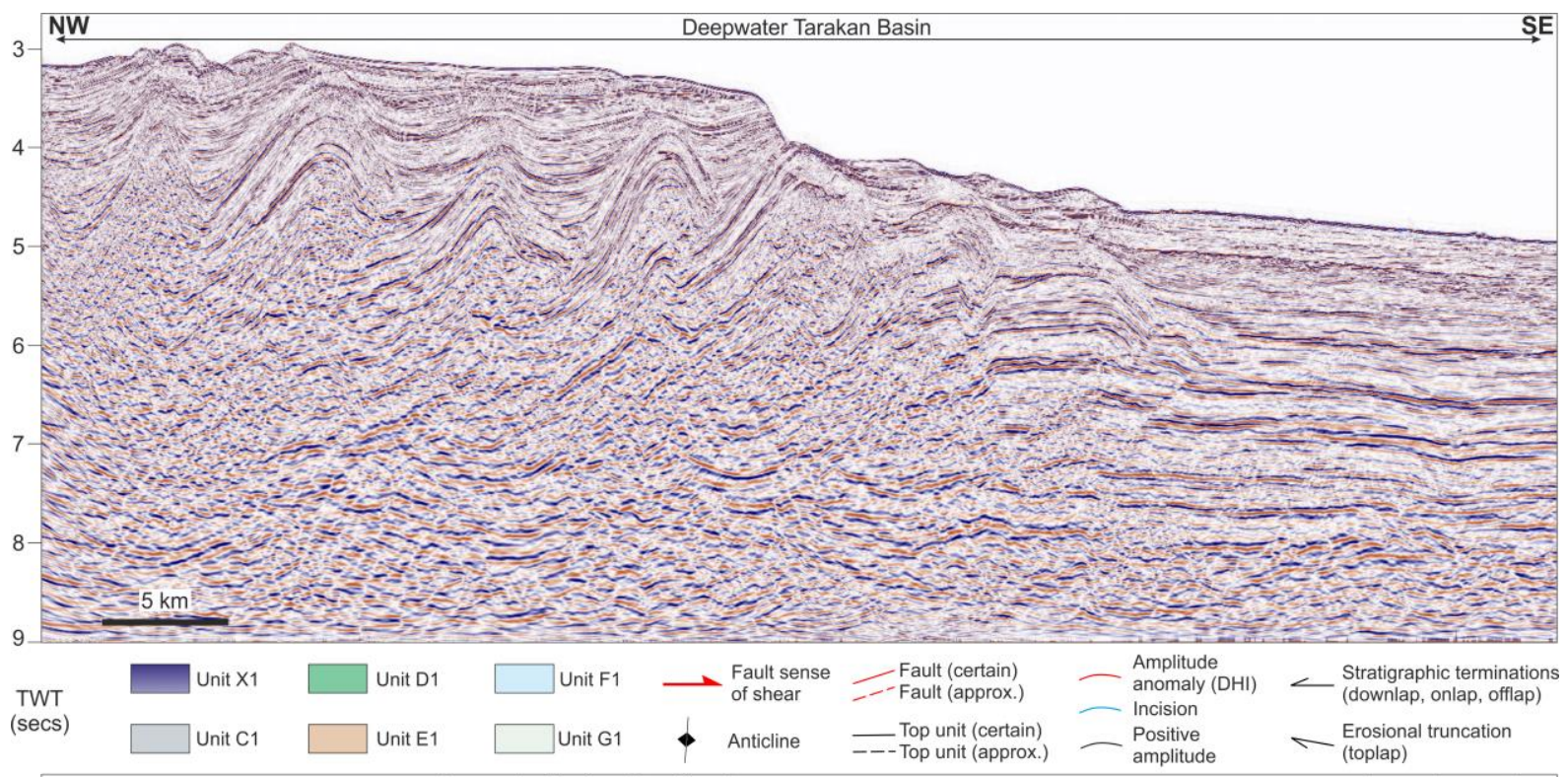

1019

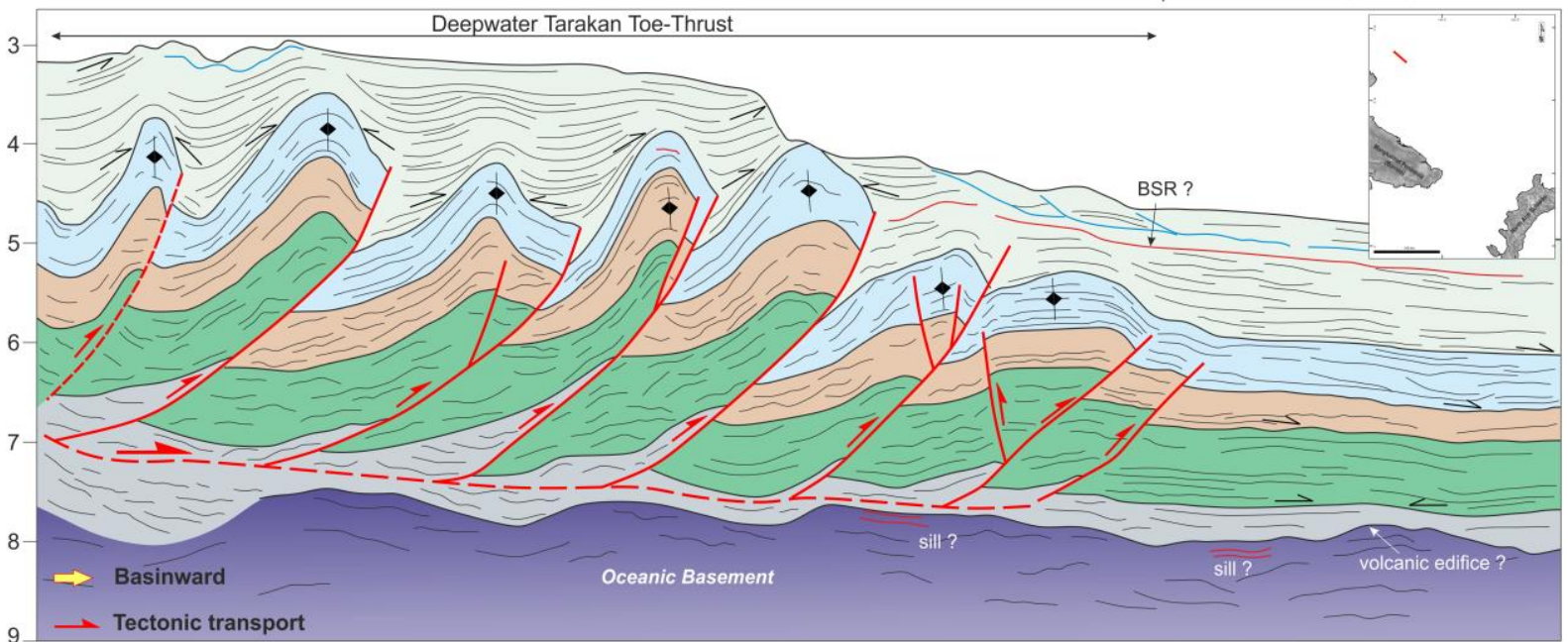

1020 Figure 14. Uninterpreted (above) and interpreted (below) NW-SE seismic section from Deepwater

1021 Tarakan Basin showing imbricated styles of fold-thrust belt in the Deepwater Tarakan Toe-Thrust. The

1022 toe-thrust deformation younging direction is to the right. Note that younger strata (Unit G1) above pre-

1023 kinematic units are not affected much by defomation of fold-thrust belt as growth strata of syn-kinematic

1024 and parallel reflection of post-kinematic above, only covered the deformed unit below. Multibeam

1025 bathymetry also shows toe-thrust not visible on the seabed (Figure 3). 

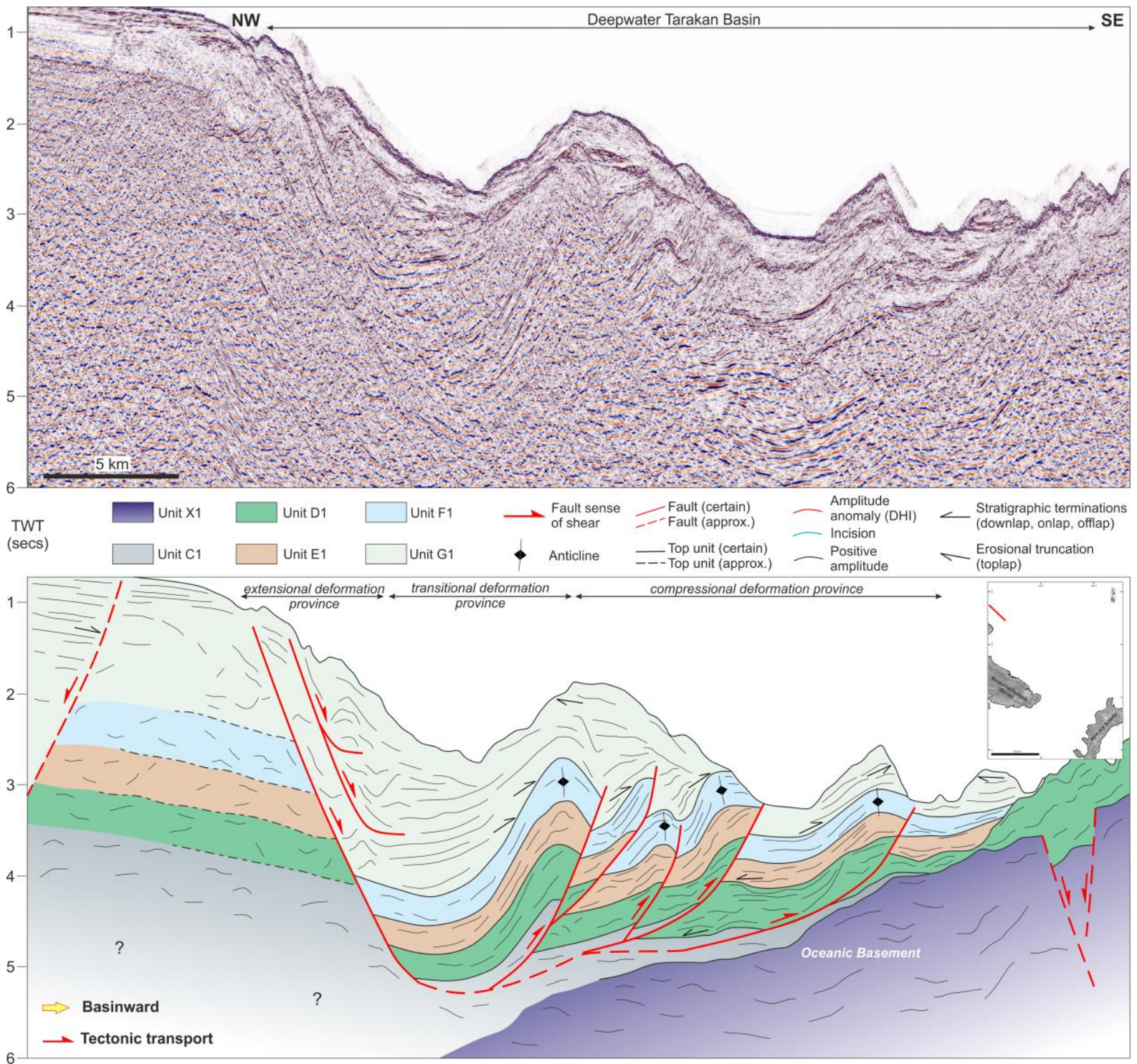

1027 Figure 15. Uninterpreted (above) and interpreted (below) NW-SE seismic section from Deepwater

1028 Tarakan Basin exhibit the development of deepwater toe-thrust. The toe-thrust development is driven by gravitational sliding from unstable shelfal area with extensional deformation province that allow large

1030 amount of sediment to fall and flow downslope to the basinward. The toe-thrust then developed as compressional deformation province. The toe-thrust deformation younging direction is to the right.

1032 Active erosional surface shaped the local incision valley at the seabed as also reflected from multibeam bathymetry shown in Figure 3. 

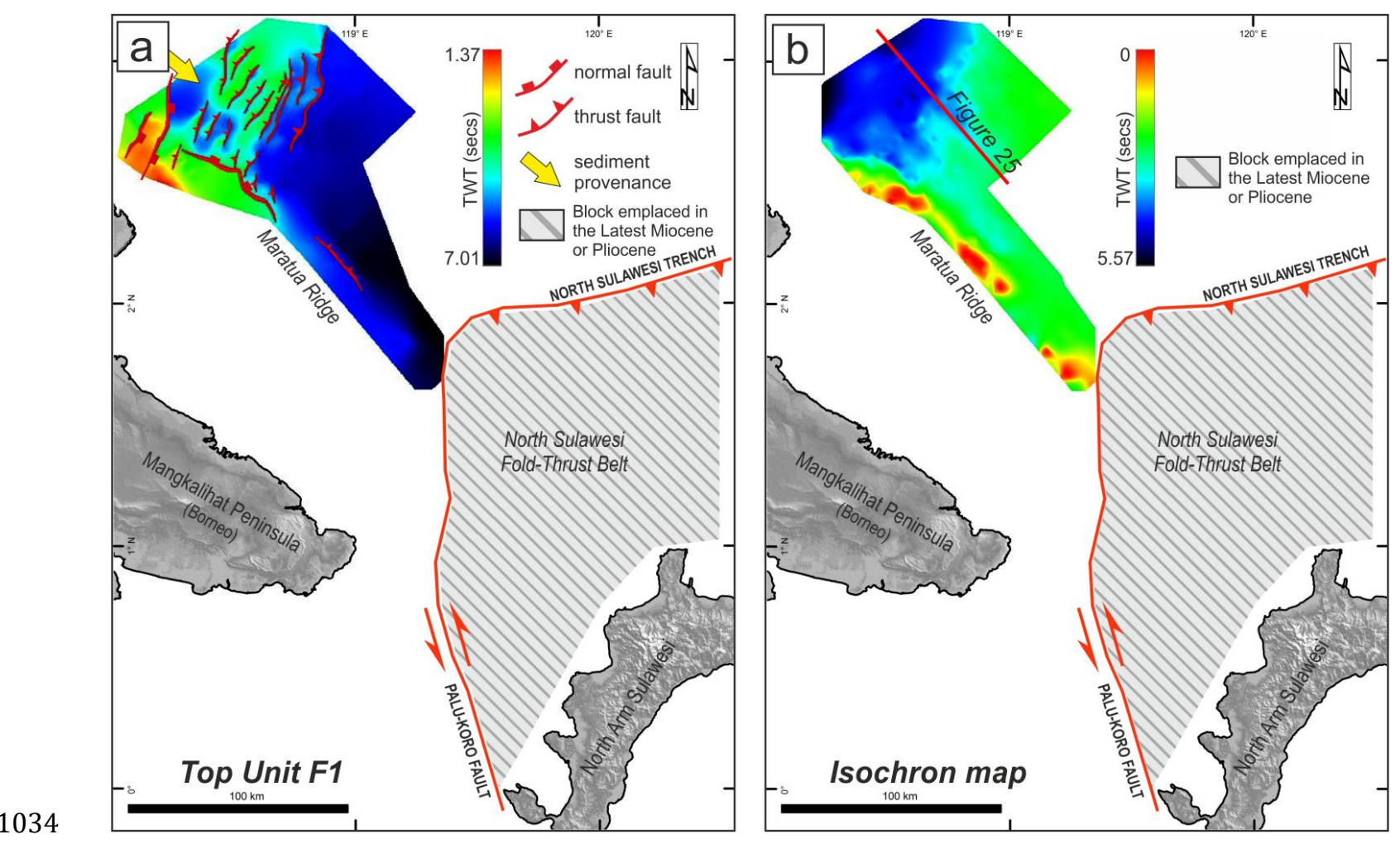

1035

Figure 16. Subsurface map of Deepwater Tarakan Basin. (a) Depth to Top Unit F1 structure map showing

1036 the well-developed gravity driven toe-thrust fault. Extensional deformation province is observed in the shallow depth level, whereas compressional deformation province is observed in the toe of the slope. (b)

1038 Total sediment thickness map showing great amount of sediment thicknesses were concentrated in the deformed area compare to the distal area to the east. 

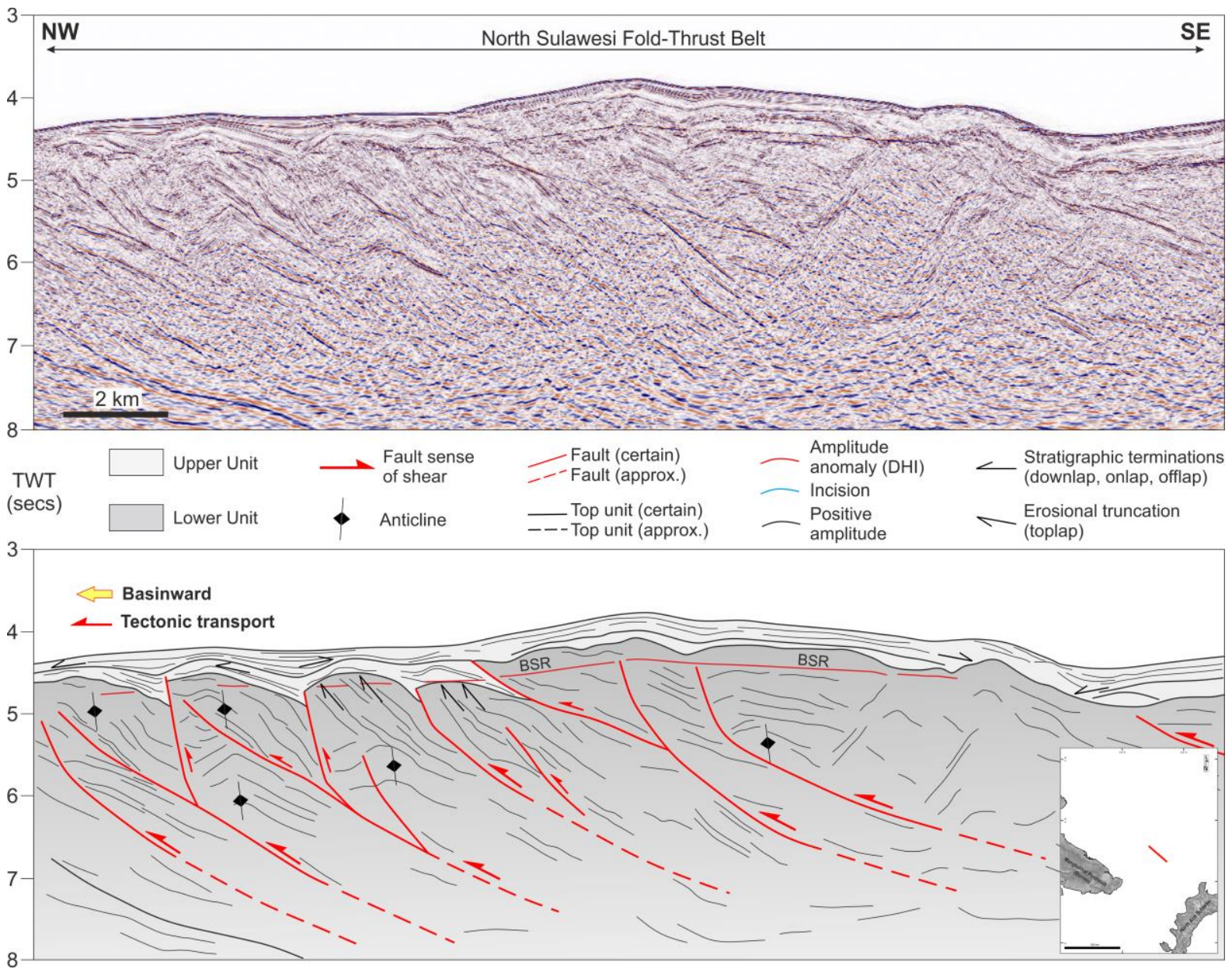

1041 Figure 17. Uninterpreted (above) and interpreted (below) NW-SE seismic section from North Sulawesi

1042 Fold-Thrust Belt. The imbricated fold-thrust belt is verging NW, different with tectonic transport of

1043 Deepwater Tarakan Toe-Thrust. Also, the seabed expression from seismic and multibeam bathymetry

1044 (Figure 3) also showing active deformation of North Sulawesi Fold-Thrust Belt in the present-day. The fold-thrust belt deformation younging direction is to the left. 

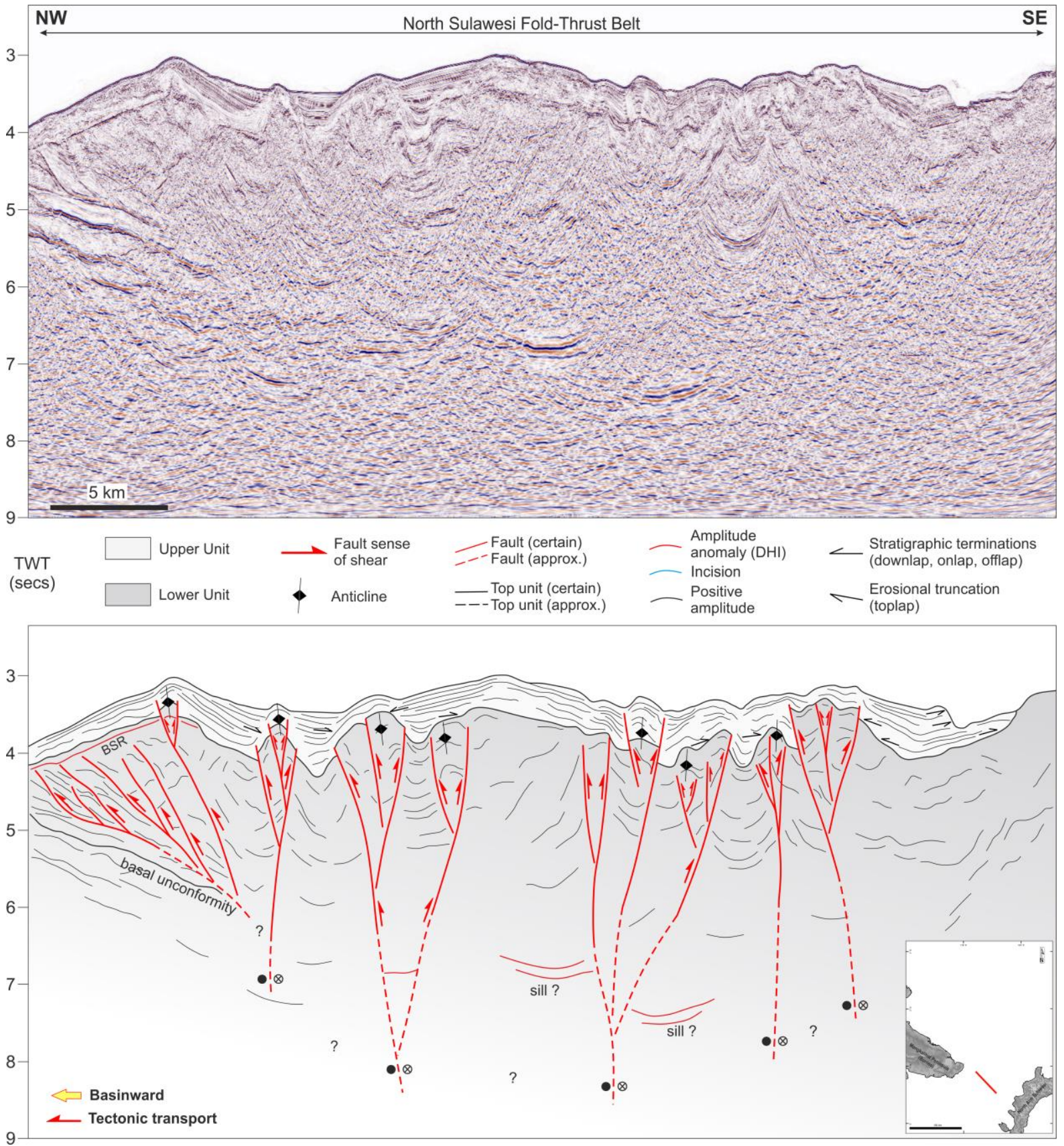

1047 Figure 18. Uninterpreted (above) and interpreted (below) NW-SE seismic section from North Sulawesi

1048 Fold-Thrust Belt. The complex Palu-Koro Fault Zone is shown in the left where there are possible

1049 underthrusting Eastern Borneo part below the fold-thrust belt. Seismic interpretation also showing

1050 several couple shears of Palu-Koro Fault Zone that controlled the morphology and sedimentary architecture of the seabed, indicating active deformation in the present-day. 

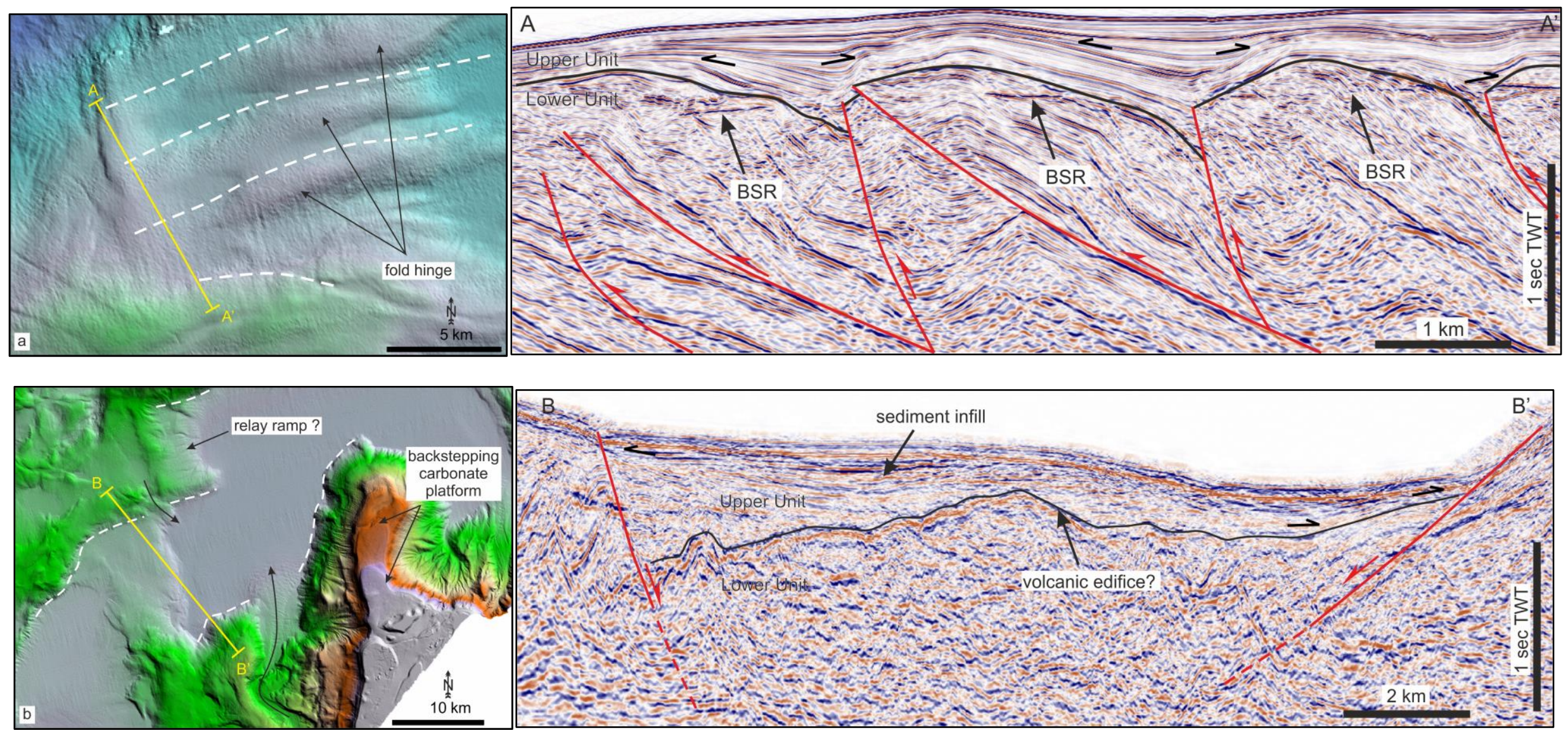

Figure 19. Structural features as observed in the North Sulawesi Fold-Thrust Belt. Illumination direction from NE. (a) Seabed morphology of the fold-thrust belt. (b)

Extensional basin formed in the southern-most part of the North Sulawesi Fold-Thrust Belt. Location is shown in Figure 3. 


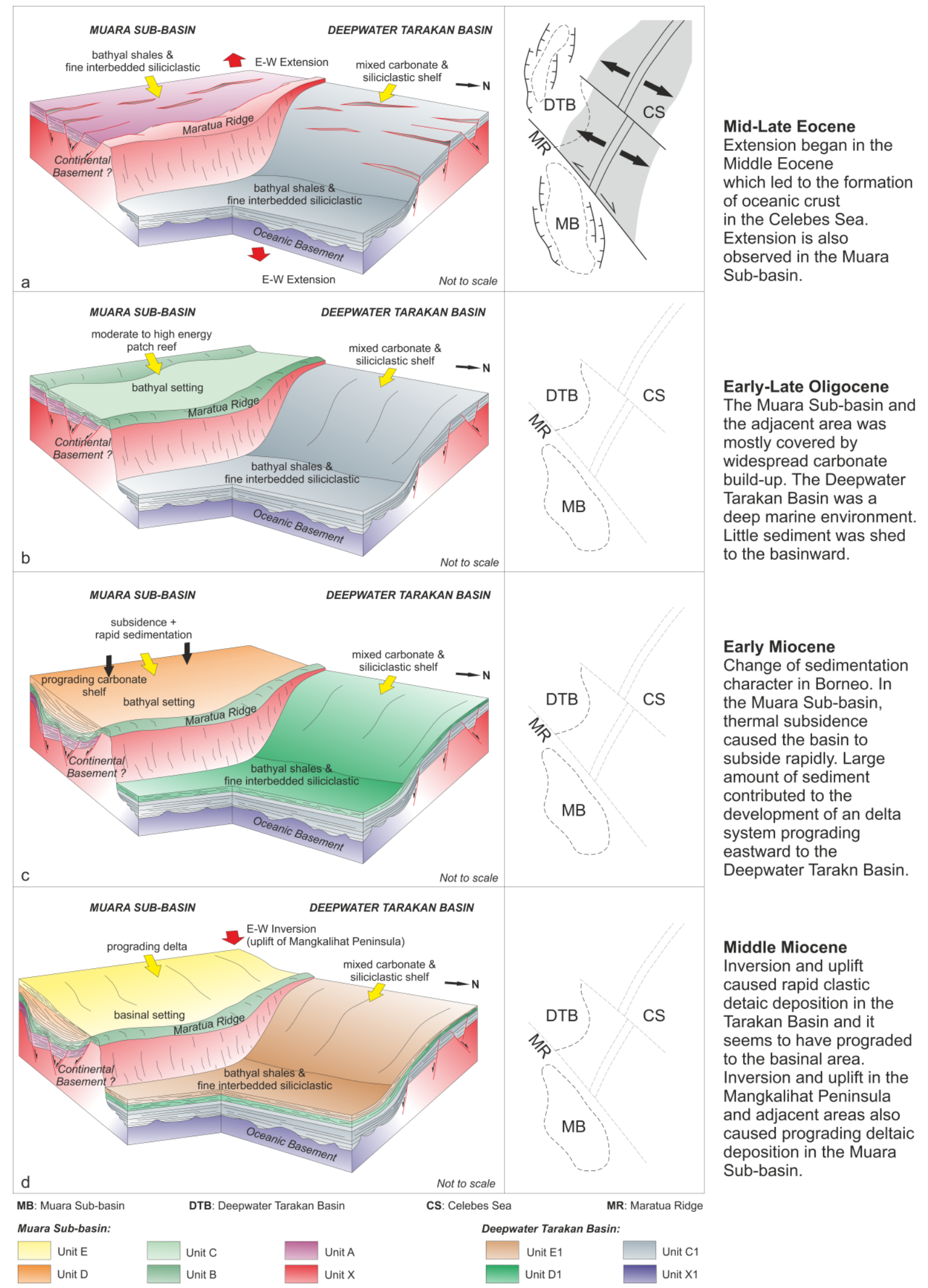

1057 Figure 20. Schematic diagram illustrating the structural and stratigraphic evolution model of the Offshore

1058 NW Sulawesi. (a) Middle-Late Eocene stage. (b) Early-Late Oligocene stage. (c) Early Miocene stage. (d) 


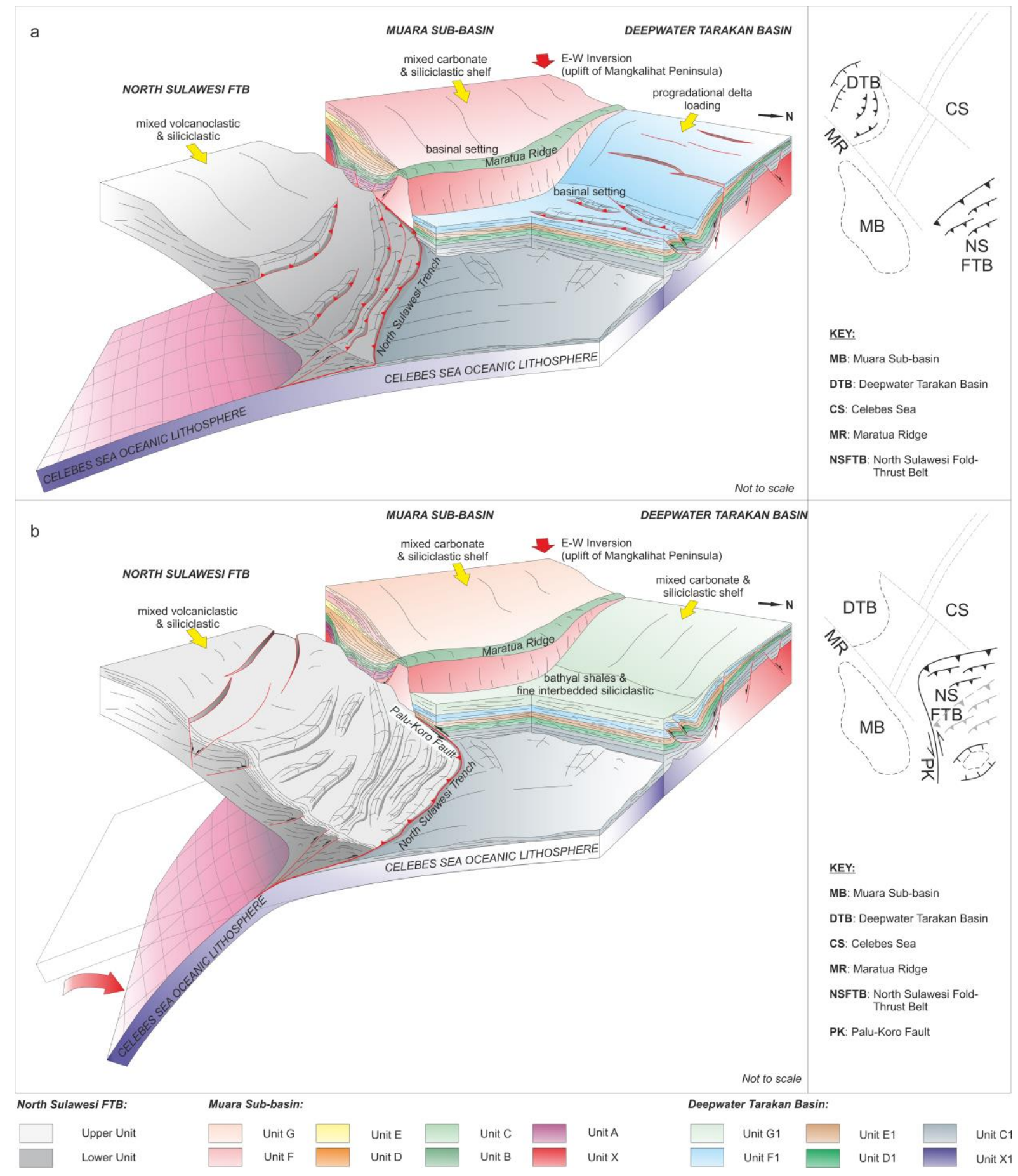

1061 Figure 21. Schematic diagram illustrating the structural and stratigraphic evolution model of the Offshore

1062 NW Sulawesi. (a) In the Late Miocene stage, inversion and uplifting seem to have continued caused mixed

1063 carbonate and siliciclastic prograded into the Muara Sub-basin. Similarly, in the Deepwater Tarakan

1064 Basin, rapid clastic deposition from landward to the basin caused loading of the prograding delta.

1065 Consequently, normal faulting in the shelf caused gravity driven movements and formed Deepwater

1066 Tarakan Toe-Thrust faults. At the same time, the subducting Celebes Sea is interpreted to have occured in

1067 the Latest Miocene and developed North Sulawesi Fold-Thrust Belt. (b) Inversion and uplift in Borneo are 
1068 interpreted to have continued from Middle Miocene until the present-day. This caused progradation of 1069 the shelf which developed during the Pliocene to present-day in both Muara Sub-basin and Deepwater 1070 Tarakan Basin. Development of toe-thrust faulting in the Deepwater Tarakan Basin is interpreted as 1071 inactive since the Pleistocene. Rollback of North Sulawesi Trench has caused clockwise rotation and 1072 moved towards the north to its present-day position, whereas immediately north of North Arm of 1073 Sulawesi in the offshore extension and subsidence were well developed, followed by deposition of Upper 1074 Unit. 


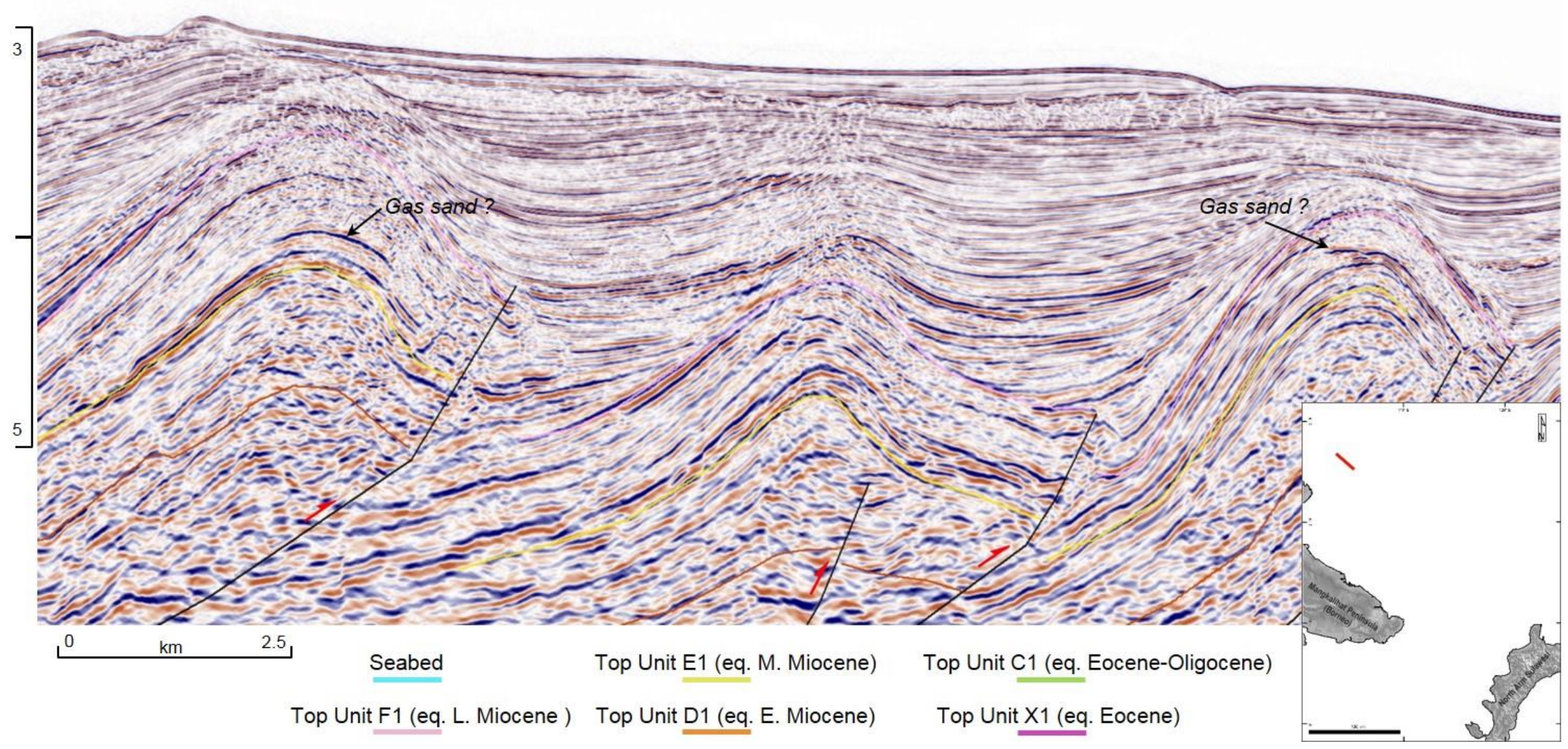




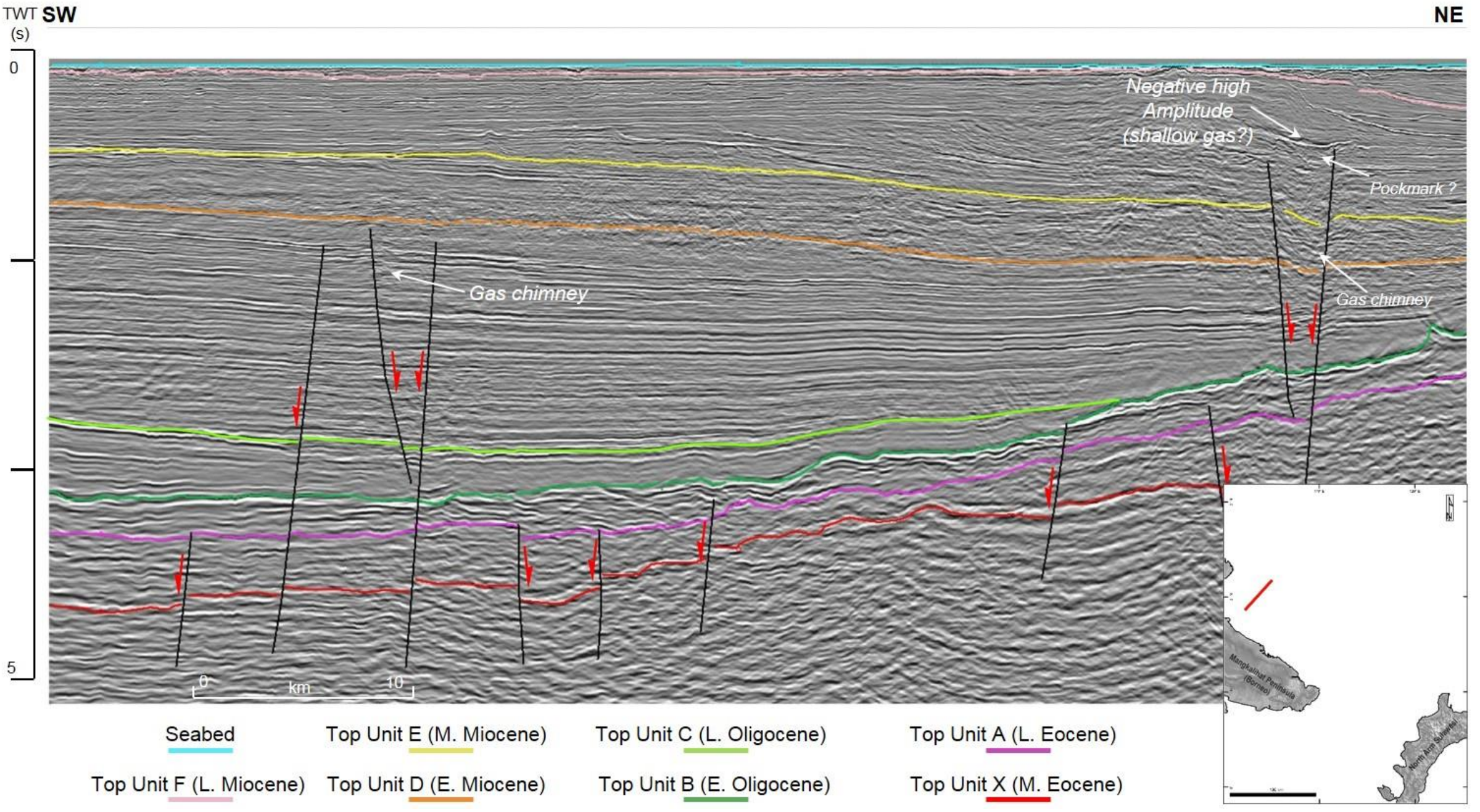




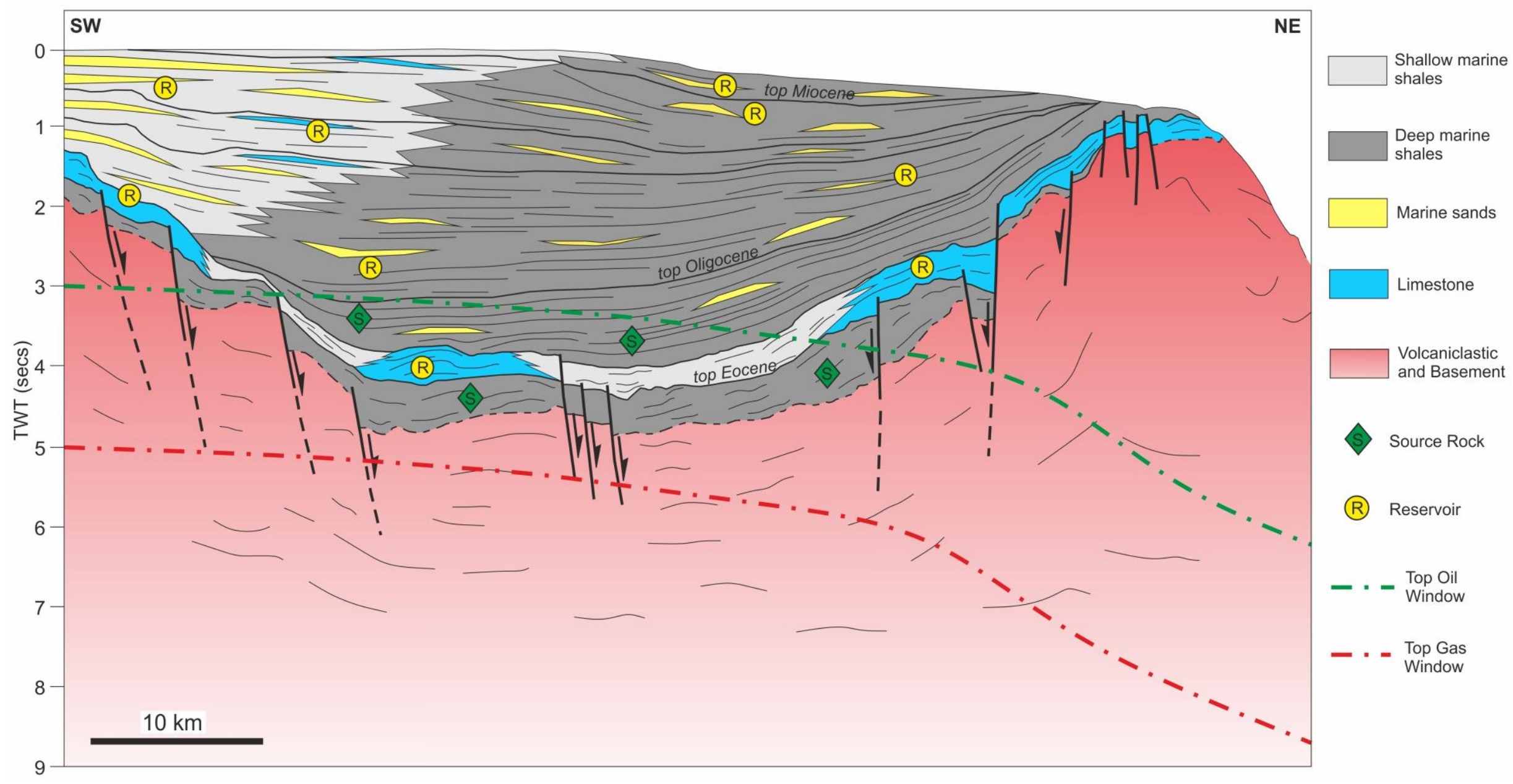

Figure 24. Schematic cartoon shows play cross-section in the Muara Sub-basin. Location is shown in Figure 10d. 


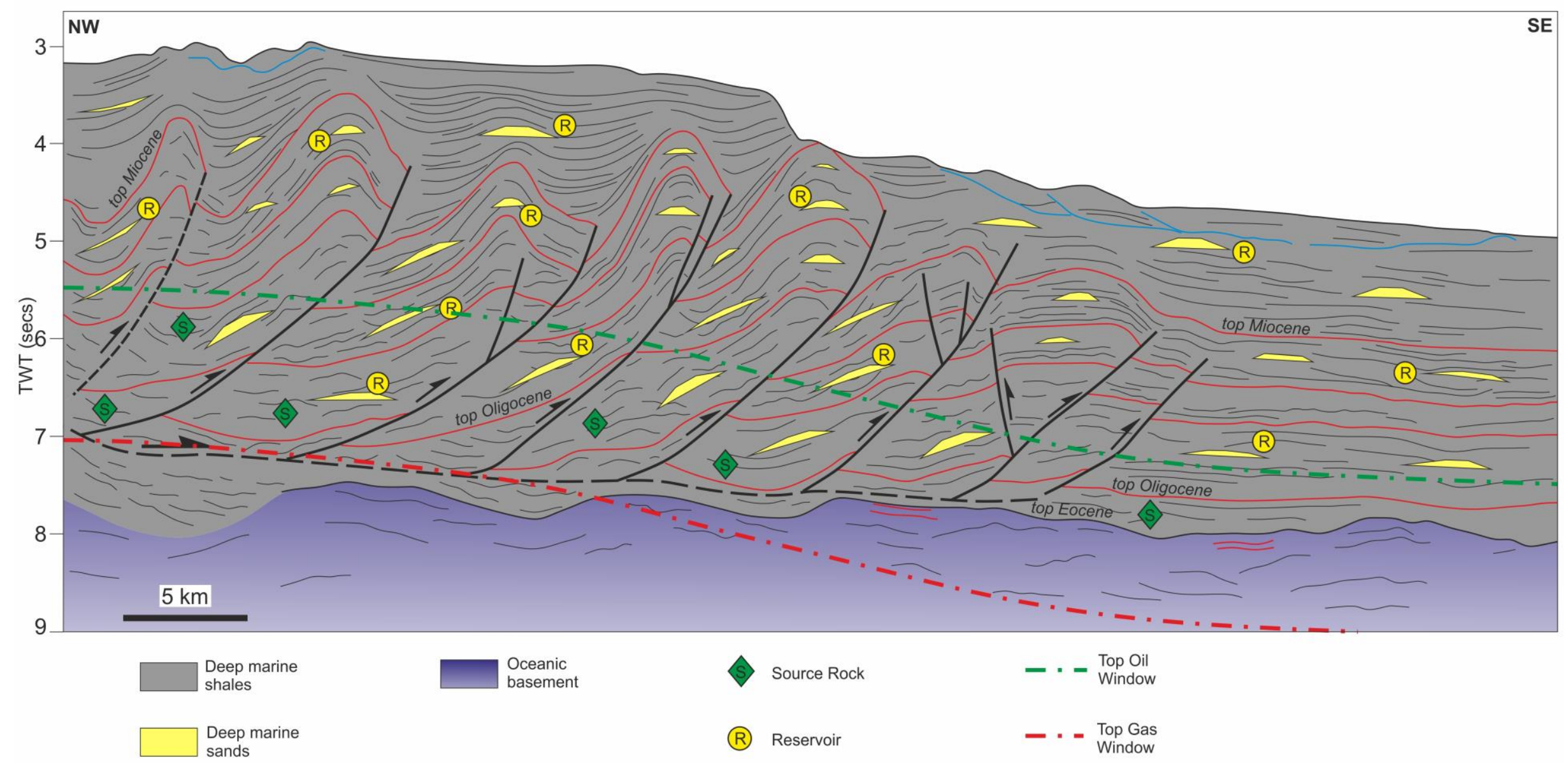

Figure 25. Schematic cartoon shows play cross-section in the Deepwater Tarakan Basin. Location is shown in Figure 16b. 